\title{
A New Species of Alopoglossus Boulenger (1885) (Squamata, Alopoglossidae) from the Lowlands of the Eastern Guiana Shield, with Assessment of the Taxonomic Status of $A$. copii surinamensis
}

\author{
Marco Antônio Ribeiro-JÚnior, ${ }^{1,2}$ Shai Meiri, ${ }^{1,3}$ AND ANTOINE FouQuet ${ }^{4}$ \\ ${ }^{1}$ School of Zoology, Tel Aviv University, Tel Aviv, Israel, 6997801 \\ ${ }^{3}$ Steinhardt Museum of Natural History, Tel Aviv University, Tel Aviv, Israel, 6997801 \\ ${ }^{4}$ Laboratoire Evolution et Diversité Biologique, UMR 5174, CNRS, IRD, Université Paul Sabatier, Bâtiment $4 R 131062$ cedex 9, 118 Route de Narbonne, \\ Toulouse, France, 31077
}

\begin{abstract}
Two species of Alopoglossus (A. angulatus and A. meloi) were recognized to occur in the Guiana Shield lowlands, northeastern Amazonia. A third group of populations forming a distinct genetic lineage related to Alopoglossus avilapiresae was recently documented in the region. The Guiana Shield lowlands area also encompasses the type locality of Alopoglossus copii surinamensis (currently considered a synonym of $A$. angulatus). Aiming at describing a possible new species of Alopoglossus from the Guiana Shield and evaluating the taxonomic status of $A$. copii surinamensis, we analyzed variation in scutellation and morphometrics of the two nominal species of Alopoglossus occurring in the Guiana Shield and A. avilapiresae, which was recovered as the sister clade of the new Guiana Shield lineage, by examining 361 specimens from French Guiana, Brazil, Suriname, Guyana, Colombia, Ecuador, and Peru. Our results revealed a distinct combination of diagnostic characters that supports the description of specimens displaying the third Guiana Shield lineage as a new species. The new species is also distinct from $A$. copii surinamensis that we retain under a synonym of $A$. angulatus after examination of all species of the angulatus group and by considering updated diagnostic characters. The new taxon described here increases the total number of known species of Alopoglossus to 15.
\end{abstract}

Resumo.-Duas espécies de Alopoglossus (A. angulatus e A. meloi) são reconhecidas nas planícies do Escudo Guianense, no nordeste da Amazônia. Um terceiro grupo de populações, formando uma linhagem distinta relacionada $\grave{a}$ A. avilapiresae, foi recentemente documentada na região. Esta área também abriga a localidade-tipo de $A$. copii surinamensis (atualmente considerada sinônimo de $A$. angulatus). Com o intuito de descrever esta possível terceira espécie de Alopoglossus do Escudo das Guianas, e avaliar o status taxonômico de $A$. copii surinamensis, nós analisamos a variação na escutelação e morfometria de duas formas nominais de Alopoglossus que ocorrem no Escudo das Guianas e A. avilapiresae, a qual foi reconhecida como grupo irmão da linhagem nova do Escudo das Guianas, através da análise de 361 espécimes da Guiana Francesa, Brasil, Suriname, Guyana, Colômbia, Ecuador e Peru. Nossos resultados revelaram uma combinação distinta de caracteres que sustentam a descrição dos espécimes da terceira linhagem do Escudo das Guianas como pertencentes a uma nova espécie. A nova espécie é também distinta de $A$. copii surinamensis, o qual mantemos como sinônimo de A. angulatus após análise de todas as espécies do grupo angulatus e considerando caracteres diagnósticos atualizados. $\mathrm{O}$ novo taxon aqui descrito aumenta o número total de espécies descritas de Alopoglossus para 15.

The Neotropical lizard genus Alopoglossus Boulenger (1885) is widely distributed across the northern portion of South America (Köhler et al., 2012; Torres-Carvajal and Lobos, 2014; RibeiroJúnior and Amaral, 2017; Ribeiro-Júnior, 2018; Ribeiro-Júnior et al., 2020), and it includes 14 known species (Alopoglossus amazonius Ruthven [1924], Alopoglossus andeanus Ruibal [1952], Alopoglossus angulatus Linnaeus [1758], Alopoglossus atriventris Duellman [1973], Alopoglossus avilapiresae Ribeiro-Júnior, Choueri, Lobos, Venegas, Torres-Carvajal, and Werneck [2020], Alopoglossus buckleyi O'Shaughnessy [1881], Alopoglossus carinicaudatus Cope [1876], Alopoglossus collii Ribeiro-Júnior, Choueri, Lobos, Venegas, Torres-Carvajal, and Werneck [2020], Alopoglossus copii Boulenger [1885], Alopoglossus embera Peloso and Morales [2017], Alopoglossus festae Peracca [1904], Alopoglossus lehmanni Ayala and Harris [1984], Alopoglossus meloi RibeiroJúnior [2018] and Alopoglossus viridiceps Torres-Carvajal and Lobos [2014]), and two putatively new species recovered by molecular analyses (Ribeiro-Júnior et al., 2020). Alopoglossus lizards are diurnal and inhabit leaf litter of Neotropical forests, plantations, and savanna-forest transitions at elevations of 302,500 meters above sea level (m a.s.l.) (Ribeiro-Júnior et al., 2008, 2020; Köhler et al., 2012; Torres-Carvajal and Lobos, 2014;

${ }^{2}$ Corresponding Author. E-mail: majunior@gmail.com DOI: $10.1670 / 20-032$
Ribeiro-Júnior and Amaral, 2017). The genus differs from Ptychoglossus Boulenger (1890) (the other genus belonging to the Alopoglossidae family; Goicoechea et al., 2016) in having keeled scales on the forelimbs (vs. smooth forelimb scales) and rhomboid, laterally imbricating dorsal scales (vs. parallel-sided dorsal scales) (Harris, 1994). A few phylogenetic studies, based on genetic data, morphological data, or both, have targeted species of Alopoglossidae (Pellegrino et al., 2001; Castoe et al., 2004; Goicoechea et al., 2016; Morales et al., 2020; Ribeiro-Júnior et al., 2020). Nonetheless, the current taxonomic status of both species and genera in the family is still controversial. For example, Morales et al. (2020) recently suggested the need to synonymize Ptychoglossus with Alopoglossus. Moreover, a revision of $A$. angulatus resulted in the delimitation of no less than eight candidate species (Ribeiro-Júnior et al., 2020). Because the specific taxonomical level of organization in the family is still controversial (several new species has been described and revalidated) and diagnostic characters are being defined and/or redefined (Ribeiro-Júnior, 2018), we adopted the taxonomy of Alopoglossidae suggested by Goicoechea et al. (2016). While some recent studies have been published (e.g., Morales et al., 2020), the study of Goicoechea et al. (2016) is still the most comprehensive phylogenetic study with Gymnophthalmoidea based on molecular data. We thus opted to conservatively 
consider Ptychoglossus as a valid genus, sharing the diagnostic apomorphies suggested by Harris (1994).

In the Guiana Shield, two species are known to occur: $A$. angulatus, widespread in the region and also distributed in other regions of eastern Amazonia, and A. meloi, restricted to the southern portion of the Guiana Shield (Ribeiro-Júnior, 2018). Ribeiro-Júnior et al. (2020) recognized a third independently evolving lineage from French Guiana, closely related to $A$. avilapiresae (Western Amazonia), both nested in a clade otherwise composed of species from western Amazonia ( $A$. amazonius, A. carinicaudatus, A. collii). An additional taxon, Alopoglossus copii surinamensis, has been described from the Guiana Shield (Lucie River, Suriname) by Brongersma (1946), but it was placed under synonym of $A$. carinicaudatus (currently A. angulatus) by Ruibal (1952), a taxonomic decision that has not been challenged since. That said, its holotype, and only known specimen of this taxon, has never been examined in any previous taxonomic revision dealing with the genus (ÁvilaPires, 1995; Köhler et al., 2012; Ribeiro-Júnior, 2018; RibeiroJúnior et al., 2020). Here, we describe a new species of Alopoglossus from French Guiana (mentioned as "A. angulatus French Guiana lineage" in Ribeiro-Júnior et al., 2020; hereinafter treated as Alopoglossus sp.), and we also evaluate the taxonomic status of $A$. copii surinamensis.

\section{Material AND Methods}

We examined 361 specimens of Alopoglossus (217 specimens of A. angulatus, 28 of $A$. amazonius, six of $A$. andeanus, 64 of $A$. avilapiresae, seven of $A$. carinicaudatus, nine of $A$. collii, 23 of $A$. meloi, and seven of Alopoglossus sp.) from Brazil, Colombia, Ecuador, French Guiana, Guyana, Peru, and Suriname (see type series in the main text and Appendix 1). Specimens are deposited in the following herpetological collections: the Muséum National d'Histoire Naturelle de Paris, France (MNHN-RA); the Naturalis Biodiversity Center, Leiden, The Netherlands (RMNH); the American Museum of Natural History, New York, NY, USA (AMNH); the Museum of Comparative Zoology, Cambridge, MA, USA (MCZ); the National Museum of Natural History, Washington, DC, USA (USNM); Museo de Zoología de la Pontificia Universidad Católica del Ecuador, Quito, Ecuador (QCAZ); Centro de Ornitología y Biodiversidad, Lima, Peru (CORDIBI); Museu Paraense Emílio Goeldi, Belém, Brazil (MPEG); Museu de Zoologia da Universidade de São Paulo, São Paulo, Brazil (MZUSP); Museu de História Natural Capão da Imbuia, Curitiba, Brazil (MHNCI); Instituto de Pesquisas Científicas e Tecnológicas do Estado do Amapá, Macapá, Brazil (IEPA); Instituto Nacional de Pesquisas da Amazônia, Manaus, Brazil (INPA-H); and Universidade de Brasília, Brasília, Brazil (CHUNB). Museum acronyms follow Sabaj-Perez (2016), except for the Paulo Bührnheim Zoological Collection, Federal University of Amazonas, Manaus, Brazil (CZPB-RP). Comparisons with other species in the genus, except the ones mentioned above, are based on the literature (see Ribeiro-Júnior et al., 2020).

The meristic characters are: dorsal scales (D), counted from the parietals posteriorly to the insertion of hindlimbs; ventrals (V), counted between the interbrachial and preanal shields; scale rows around the midbody $(\mathrm{Mb})$; scale rows around the tail $(\mathrm{xx})$,

?2 immediately posterior to the cloaca; supraoculars (So); suboculars (Sbo); postoculars (Po); superciliaries (Sc); loreal (L); frenocular (Fr); supralabials (Sl); infralabials (Il); scales on sides of neck (Neck), in transverse rows; pairs of chin shields (Pairs); small or granular scales between the pairs of chin shields
(BtwP); gulars $(\mathrm{G})$, counted between the interbrachial and mental plates; femoral pores (Pores); lamellae under fourth finger $(\mathrm{F})$; lamellae under fourth toe $(\mathrm{T})$. The measurements are: snout-vent length (SVL), from the border of cloaca to the tip of snout; axilla-groin length (AGL), from the anterior margin of the hindlimb to the posterior margin of the forelimb; head depth (HD) at the highest point dorsoventrally; head length (HL) from the anterior margin of tympanic aperture to the tip of snout; forelimb length (FL); hind limb length (HLL); head width (HW) at the widest point; neck length (NL), from the posterior margin of the tympanic aperture to the anterior margin of the forelimb; shank length (ShL); tail length (TL). Measurements were taken with digital calipers $( \pm 0.1 \mathrm{~mm})$; scale counts and other morphological characters were observed using a stereomicroscope. The nomenclature of scale characters follows RibeiroJúnior (2018) and Ribeiro-Júnior et al. (2020).

Quantitative morphological distinctness between Alopoglossus sp., A. angulatus, A. meloi (species endemic to, or distributed in, the Guiana Shield), and A. avilapiresae (recovered by RibeiroJúnior et al. 2020 as sister taxa of Alopoglossus sp.) was tested using univariate and multivariate statistics. We compared means using a one-way analysis of variance (ANOVA) in $\mathrm{R}$ (with species as main factor; the same mentioned above) and used a Tukey honestly significant difference (HSD) to assess the probability of pairwise comparisons. We also performed four principal components analyses (PCA) with Alopoglossus sp., A. angulatus, A. meloi, and A. avilapiresae (PCA implemented in PAST v.3.26 software; Hammer et al., 2001): one including all examined specimens and all meristic characters (except femoral pores); one considering only males, including femoral pores (with all meristic characters); one considering only females (all meristic characters, except pores); and one including all specimens (males and females) for all measurements (except tail lengh).

Coloration in life was based on photographs of specimens in life, coloration in preservative based on holotype, and variations on it based on specimens deposited in the herpetological collections cited above. A distribution map was created using data on all examined specimens; geographical coordinates are in WGS 1984 datum. We created the distribution map using QGis Las Palmas (v.2.18.3; http://www.qgis.org/es/site/).

The description format of the new species follows RibeiroJúnior et al. $(2016 ; 2020)$. We used the standardization of the nomenclature of alopoglossid and gymnophthalmid morphological characters suggested by Ribeiro-Júnior (2018).

\section{RESULTS}

Quantitative Analyses of Morphological Data.-Statistical analyses revealed variable degrees of morphological divergence in meristic characters and measurements among Alopoglossus sp., A. angulatus, $A$. meloi, and $A$. avilapiresae, with 12 characters presenting significant differences between species in a one-way ANOVA (Table 1). Moreover, we found significant differences in Tukey's pairwise comparisons between Alopoglossus sp. and the other species in midbody (Mb), scales on sides of neck (Neck), suboculars (Sbo), scales between third pair of chin shields (BtwP), lamellae under fourth toe (T), snout-vent length (SVL) and head length (HL) (Table 1). Femoral pores in males were not included in these tests because no variance was found in Alopoglossus sp. (all specimens have 22 femoral pores). However, our relatively small sample size for Alopoglossus sp. $(n=6)$ precluded definitive statistical results. 
TABLE 1. One-way ANOVA with species as the main effects $\left(n=\right.$ residuals; ${ }^{*}=$ differences between all species [Alopoglossus angulatus, A. avilapiresae, A. meloi, and Alopoglossus sp.] and also between pairwise comparisons of Alopoglossus sp. and other species; ${ }^{* *}=$ differences between all species only; Tukey HSD posthoc test, at $\alpha=0.05$ ).

\begin{tabular}{|c|c|c|c|}
\hline Meristic characters $(n=274)$ & $F$ & $P$ & Significant contrasts, Tukey HSD \\
\hline $\mathrm{D}$ & 15.29 & $<0.00001^{* *}$ & None \\
\hline $\mathrm{V}$ & 0.883 & 0.45 & None \\
\hline $\mathrm{Mb}$ & 8.94 & $0.00001^{*}$ & Alopoglossus angulatus-Alopoglossus sp. $(P=0.015)$ \\
\hline So & 1.744 & 0.158 & None \\
\hline Sbo & 5.306 & $0.00144^{*}$ & $\begin{array}{l}\text { Alopoglossus angulatus-Alopoglossus sp. }(P=0.044) \\
\text { Alopoglossus avilapiresae-Alopoglossus sp. }(P=0.003)\end{array}$ \\
\hline Sc & 0.603 & 0.614 & None \\
\hline Sl & 8.829 & $0.00001^{* *}$ & None \\
\hline Il & 2.316 & 0.076 & None \\
\hline Po & 25.49 & $<0.00001^{* *}$ & None \\
\hline Neck & 345.4 & $<0.00001^{*}$ & $\begin{array}{l}\text { Alopoglossus angulatus-Alopoglossus sp. }(P=0) \\
\text { Alopoglossus avilapiresae-Alopoglossus sp. }(P=0) \\
\text { Alopoglossus meloi-Alopoglossus sp. }(P=0)\end{array}$ \\
\hline Btw & 22.31 & $<0.00001^{*}$ & Alopoglossus angulatus-Alopoglossus sp. $(P=0.008)$ \\
\hline G & 2.865 & $0.0371^{* *}$ & None \\
\hline $\mathrm{F}$ & 2.39 & 0.069 & None \\
\hline $\mathrm{T}$ & 7.025 & $0.0001^{*}$ & Alopoglossus angulatus-Alopoglossus sp. $(P=0.005)$ \\
\hline SVL & 4.09 & $0.0086^{*}$ & Alopoglossus avilapiresae $=$ Alopoglossus sp. $(P=0.01)$ \\
\hline AGL & 3.015 & $0.033^{* *}$ & None \\
\hline $\mathrm{HD}$ & 2.103 & 0.104 & None \\
\hline HW & 1.214 & 0.308 & None \\
\hline HL & 4.814 & $0.0035^{*}$ & $\begin{array}{l}\text { Alopoglossus angulatus }- \text { Alopoglossus sp. }(P=0.005) \\
\text { Alopoglossus avilapiresae }=\text { Alopoglossus sp. }(P=0.002)\end{array}$ \\
\hline NL & 0.168 & 0.9175 & None \\
\hline FL & 2.932 & 0.2 & None \\
\hline HLL & 5.485 & 0.28 & None \\
\hline SL & 2.142 & 0.099 & None \\
\hline TL & 0.617 & 0.607 & None \\
\hline
\end{tabular}

Our multivariate analyses failed to discrimate among species. The first two components of the PCA using 15 meristic characters (all characters, except femoral pores) and including all specimens of Alopoglossus sp., A. angulatus, A. meloi, and A. avilapiresae (males and females) failed in presenting a visual separation between Alopoglossus species (Fig. 1A). The first two components explained only $54.4 \%$ of the total variance in the characters (30\% and $24 \%$, respectively), and the most important characters in the first component were scales between the third pair of chin shields and transverse rows of scales on sides of neck, and in the second component they were dorsal scales and scales between the third pair of chin shields. In the PCA considering only males of Alopoglossus sp., A. angulatus, A. meloi, and $A$. avilapiresae and all meristic characters $(n=16)$, the first two components explained $52.1 \%$ of total variance in the characters $(27.2 \%$ and $24.9 \%$, respectively), and the most important characters in the first component were femoral pores and scales between the third pair of chin shields and in the second component they were lamellae under fourth toe and transverse rows of scales on sides of neck. This PCA recovered total separation between Alopoglossus sp. and A. angulatus- $A$. avilapiresae and partial overlapping between Alopoglossus sp. and A. meloi (Appendix 2). In the PCA considering only females of Alopoglossus sp., A. angulatus, A. meloi, and A. avilapiresae and all meristic characters $(n=15$, except femoral pores), the first two components explained $48.0 \%$ of total variance in the characters $(27.5 \%$ and $20.4 \%$, respectively) and presented an overlapping of all species (Appendix 2). The most important characters in the first component in this PCA were infralabials and scales between the third pair of chin shields and in the second component they were dorsal scales and transverse rows of scales on sides of neck.

The first two components of the PCA using all measurements ( $n=9$, except tail lengh), and including all specimens of Alopoglossus sp., A. angulatus, A. meloi, and A. avilapiresae (males and females) also failed in presenting a visual separation between Alopoglossus sp. and others species (Fig. 1B). The first two components in this PCA explained $93.6 \%$ of the total variance in the characters ( $83.4 \%$ and $10.2 \%$, respectively); the most important characters in the first component were snoutvent length and axilla-groin length and in the second component they were hind limb and forelimb lengths.

Taxonomic Status of Alopoglossus sp.-Based on the congruences between molecular (see Ribeiro-Júnior et al., 2020) and morphological analyzes (quantitative and qualitative informative characters recovered by the present study), we hereafter describe Alopoglossus sp., presenting its distribution and a summary of scalation character and measurements variation. We provide detailed comparisons of the new species with all species of the $A$. angulatus group, and we also present an evaluation of the taxonomic status of $A$. copii surinamensis.

Reptilia: Squamata. Gymnophthalmoidea Fitzinger, 1826

Alopoglossidae Goicoechea, Frost, De la Riva, Pellegrino, Sites, Rodrigues, and Padial, 2016 Alopoglossus Boulenger, 1885 Alopoglossus theodorusi sp. nov.

(Figs. 1-11; Tables 1, 2)

Alopoglossus "French Guiana lineage" Ribeiro-Júnior et al. (2020:6,7,37,39; figs. 2, 3, 20, S1-S3 in that study) 

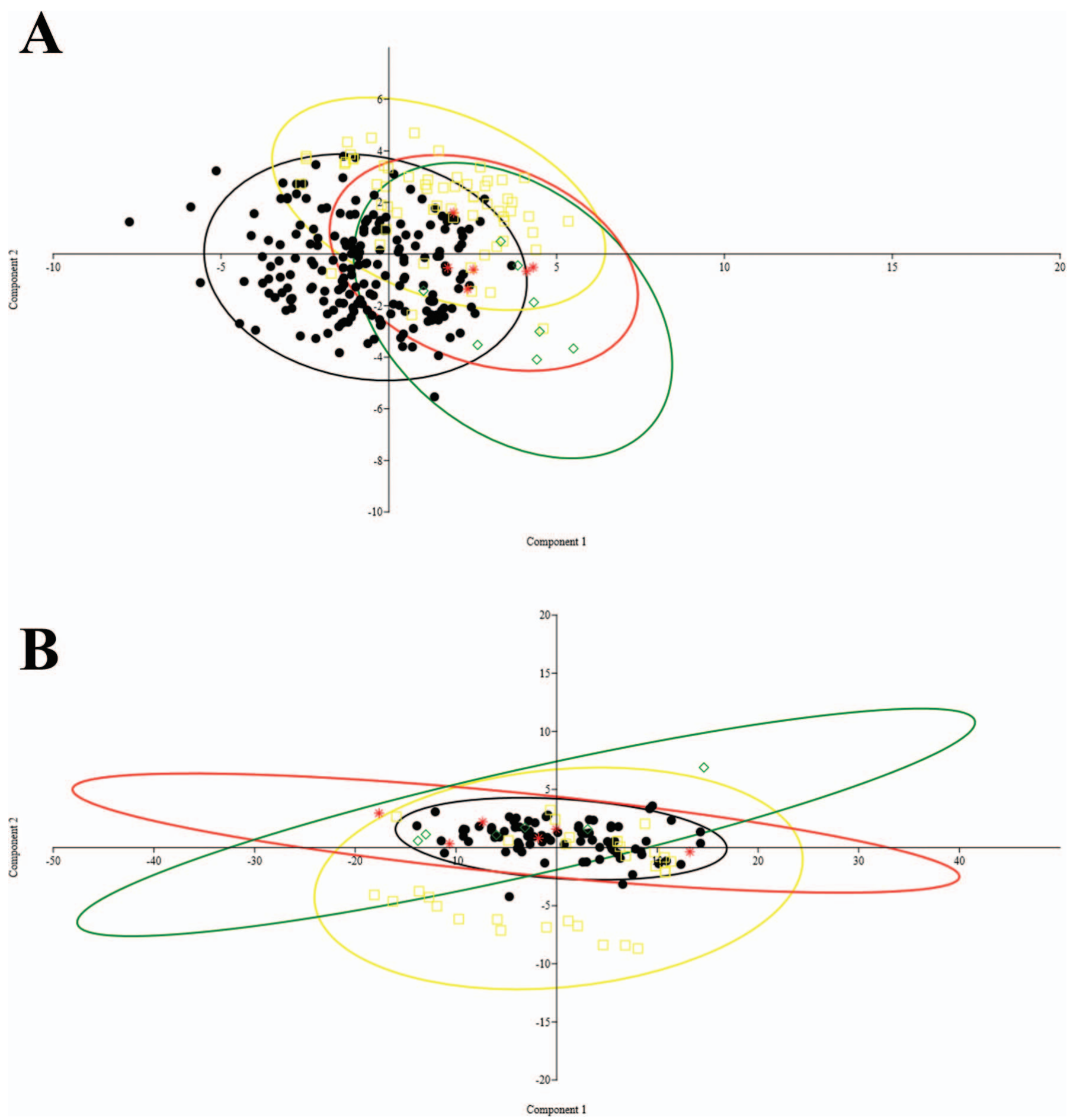

Fig. 1. Principal component analysis (PCA) of (A) meristic characters and (B) measurements between specimens of A. angulatus (black dots), A. avilapiresae (yellow squares), A. meloi (green diamonds), and "Alopoglossus sp." (red stars).

Holotype.-Adult female, MNHN-RA-2020.0019, from Saut Maripa, St. Georges, French Guiana $\left(3^{\circ} 48^{\prime} 40.17^{\prime \prime} \mathrm{N}\right.$, $\left.51^{\circ} 53^{\prime} 22.72^{\prime \prime} \mathrm{W}\right)$, collected on 03 May 2012, by A. Fouquet, field number AF740 (Figs. 2, 3).

Paratypes.-Two specimens: adult female, MNHN-RA-2020. 0020, from Armontabo, French Guiana ( $3^{\circ} 51^{\prime} 50^{\prime \prime} \mathrm{N}, 52^{\circ} 29^{\prime} 18^{\prime \prime} \mathrm{W}$ ), collected on 30 August 2003, by P. Gaucher, field number PG172; adult female, MNHN-RA-2020.0021, from Mont Galbao, French Guiana $\left(4^{\circ} 29^{\prime} 17^{\prime \prime} \mathrm{N}, 52^{\circ} 02^{\prime} 40^{\prime \prime} \mathrm{W}\right)$, collected on 19 October 2018 , by E. Courtois \& M. Dewynter, field number AF4793.
Referred Specimens.-MNHN-RA-1996.4471-73, males, Camp de Saint-Eugène, French Guiana $\left(4^{\circ} 51^{\prime} 02^{\prime \prime} \mathrm{N}, 5^{\circ} 03^{\prime} 21^{\prime \prime} \mathrm{W}\right), 7-27$ September 1993, I. Ineich; MNHN-RA-2001.358, juvenile, DZ n 5 , French Guiana $\left(4^{\circ} 03^{\prime} \mathrm{N}, 52^{\circ} 01^{\prime} \mathrm{W}\right)$, M. Blanc; MNHN-RA2020.0022, MNHN-RA-2020.0023, male and female, DZ n'5, French Guiana $\left(4^{\circ} 03^{\prime} \mathrm{N}, 52^{\circ} 01^{\prime} \mathrm{W}\right), 15$ September 2001 , M. Blanc, field numbers RG5 and RG6. Photographs of specimens in life from Lourenço, Amapá, Brazil $\left(2^{\circ} 19^{\prime} 18^{\prime \prime} \mathrm{N}, 51^{\circ} 36^{\prime} 39^{\prime \prime} \mathrm{W}\right), 07$ December 2012, S. Marques de Souza, J. Dias Lima, A. Fouquet; 


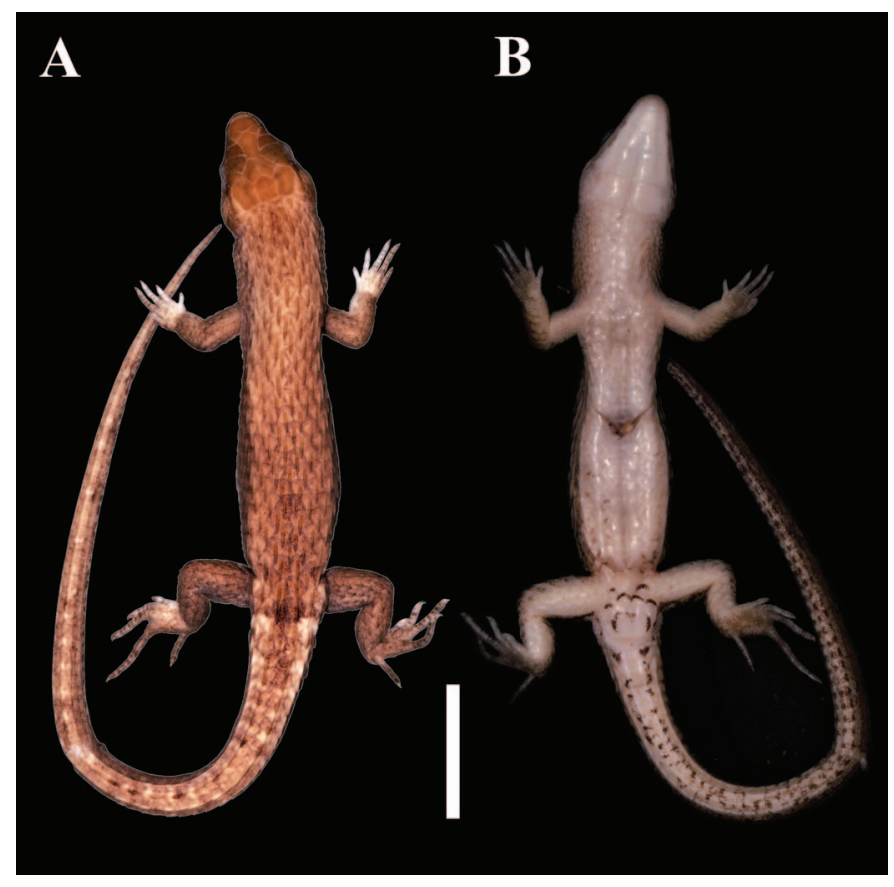

FIG. 2. (A) Dorsal and (B) ventral views of the holotype of Alopoglossus theodorusi sp. nov. (MNHN-RA-2020.0019). Scale bar $=1$ $\mathrm{cm}$.

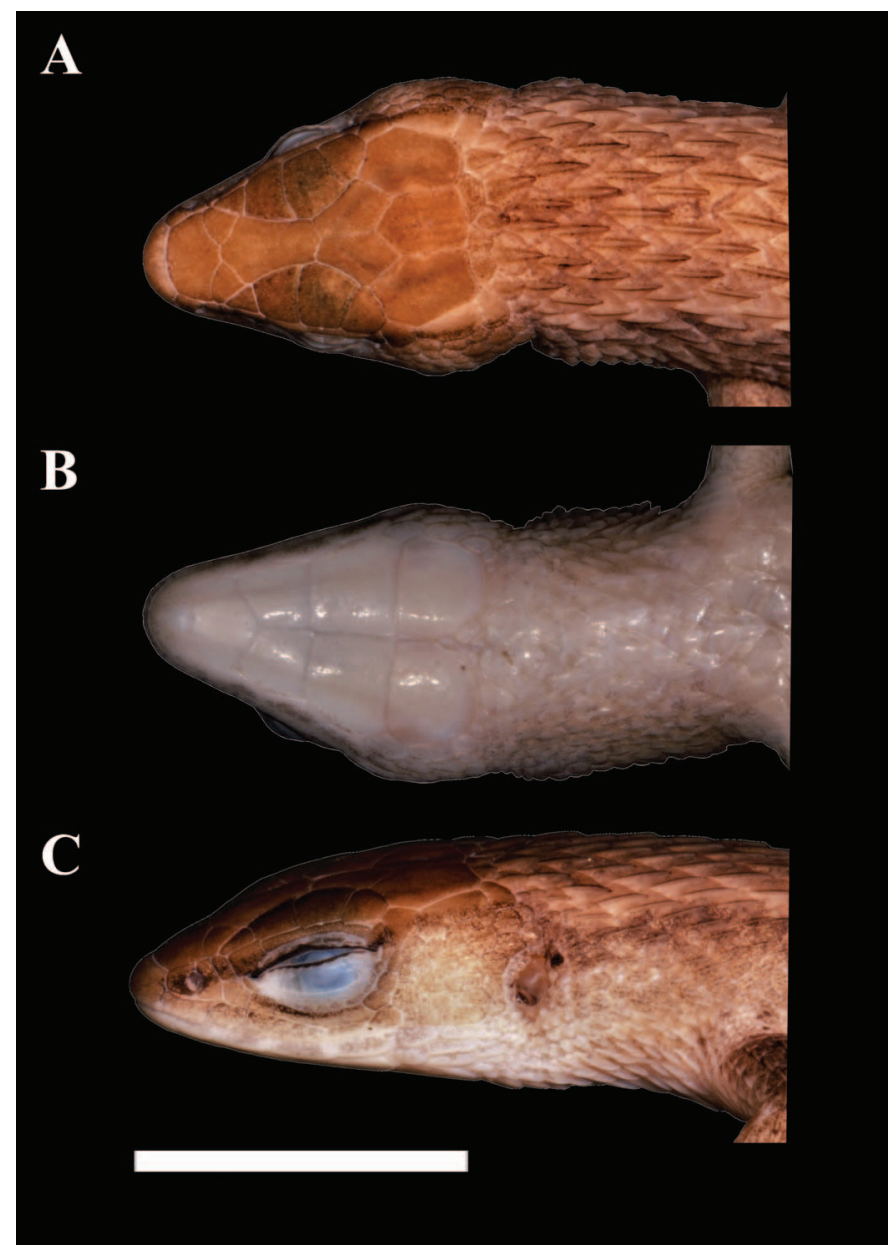

FIG. 3. (A) Dorsal, (B) ventral, and (C) lateral views of the head and neck of the holotype of Alopoglossus theodorusi sp. nov. (MNHN-RA2020.0019). Scale bar $=1 \mathrm{~cm}$. from Mont Belvedere, near Saul, French Guiana $\left(3^{\circ} 43^{\prime} 10^{\prime \prime} \mathrm{N}\right.$, $\left.53^{\circ} 24^{\prime} 46^{\prime \prime} \mathrm{W}\right)$.

Diagnosis.-Alopoglossus theodorusi sp. nov. is distinguished from all other species of Alopoglossus by the combination of the following characters: (1) scales on sides of neck keeled, imbricate (at least medial and posterior ones phylloid), in 9-10 transverse rows; (2) prefrontals separated from each other by the contact between frontonasal and frontal, or prefrontals with a short contact between them; (3) three pairs of chin shields; (4) third pair of chin shields with rounded posterior margins, in direct contact with gulars; scales of the third pair of chin shields in contact with each other anteriorly, and separated from each other by small scales posteriorly; (5) temporal scales smooth or feebly keeled (temporal region with a smooth general aspect).

Comparison with Other Species.-Alopoglossus theodorusi sp. nov. differs from A. atriventris, A. buckleyi, A. copii, A. embera, A. festae, A. lehmanni, and $A$. viridiceps (in parenthesis) in having scales on sides of neck similar in shape to dorsals, nongranular, keeled, imbricate (granular in $A$. atriventris and A. buckleyi; mostly granular in A. embera, A. festae, A. lehmanni, and A. viridiceps; conical with apparent bare skin between conical scales in $A$. copii); it also differs from $A$. embera, A. festae and A. viridiceps in having gulars not in two longitudinal rows (vs. a double longitudinal row of widened gular scales); from A. lehmanni in having dorsal scales rhomboidal, in oblique rows (vs. dorsal scales hexagonal with parallel lateral edges, in transverse rows); from $A$. atriventris and $A$. buckleyi in having three pairs of chin shields (vs. four pairs).

In the Alopoglossus angulatus species group, Alopoglossus theodorusi sp. nov. differs from $A$. meloi (also distributed in the Guiana Shield lowlands) and A. amazonius in having three pairs of chin shields (vs. four pairs; Fig. 4), and third pair of chin shields with rounded posterior margins, in direct contact with gulars (vs. third pair irregularly trapezoidal, separated from gulars by large scales; Fig. 4); it also differs from A. meloi in having scales on sides of neck in 9-10 transverse rows (vs. 6-8), and from A. amazonius in having lower number of femoral pores in males (22 vs. 24-28). Alopoglossus theodorusi sp. nov. differs from $A$. angulatus (distributed in eastern Amazonia, and occurring in sympatry with Alopoglossus theodorusi sp. nov. in the eastern Guiana Shield) in having prefrontals widely separated from each other by the contact between frontonasal and frontal or prefrontals with a short contact with each other (vs. prefrontals with a wide contact with each other medially; Fig. 5A-C), scales of the third pair of chin shields in contact with each other anteriorly (vs. scales of the third pair of chin shields completely separated from each other by small scales; Fig. 5D, $5 \mathrm{E})$, temporal scales smooth or weakly keeled, with a smooth general aspect (vs. temporal scales strongly keeled; Fig. 6), and a higher number of transverse rows of scales on sides of neck (910 vs. 6-9). Alopoglossus theodorusi sp. nov. differs from $A$. avilapiresae (the closest related species) in having prefrontals widely separated from each other by the contact between frontonasal and frontal or prefrontals with a short contact with each other (vs. prefrontals with a long contact with each other medially; Fig. 7), lower number of transverse rows of scales on sides of neck (9-10 vs. 10-13), and lower number of femoral pores in males (22 vs. 23-29). Alopoglossus theodorusi sp. nov. differs from $A$. andeanus and $A$. carinicaudatus in having lower number of transverse rows of scales on sides of neck (9-10 vs. 11-12), and lower number of femoral pores in males (22 vs. $24-$ 28 in A. andeanus and $22-26$ in A. carinicaudatus); it also differs from $A$. andeanus by absence of a distinct, enlarged medial pair 


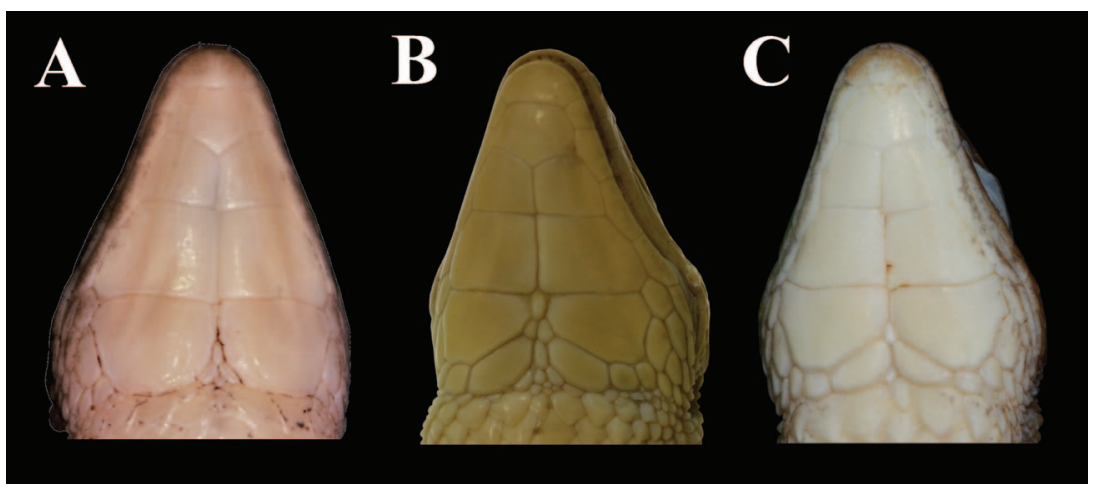

Fig. 4. Ventral views of the head of the (A) paratype of Alopoglossus theodorusi sp. nov. (MNHN-RA-2020.0020), (B) holotype of Alopoglossus amazonius (UMMZ 56853), and (C) holotype of Alopoglossus meloi (MPEG 24372).

of pregular scales (Fig. 8) and from A. carinicaudatus by having third pair of chin shields rounded posteriorly (vs. third pair of chin shields irregularly quadrangular, with anterior and posterior margins almost parallel, straight; Fig. 8). It differs from $A$. colli in having smooth general aspect of temporals (vs. strongly keeled temporals; Fig. 9), higher number of transverse rows of scales on sides of neck (9-10 vs. 8-9), and higher number of femoral pores in males (22 vs. 19-22).

Description of Holotype.-Body cylindrical; snout rounded; head, neck, and body similar in width; limbs well developed; tail 1.65 times longer than body (Fig. 2). Female. Rostral hexagonal, in broad contact with frontonasal, but also with first supralabial and nasal. Viewed dorsally, the rostral is about four times as wide as high. Frontonasal irregularly hexagonal, wider than long (wider posteriorly); anteriorly in contact with rostral; laterally with nasal; posteriorly with prefrontals and frontal. Prefrontals irregularly trapezoidal (almost triangular), as wide as long, widely separated from each other by the contact between frontonasal and frontal; laterally in contact with nasal, loreal, and first supraocular; posteriorly in contact with frontal. Frontal irregularly heptagonal (anteriorly curly bracket shaped), longer than wide (distinctly wider anteriorly); laterally in contact with first, second, and third supraoculars; posteriorly in contact with frontoparietals. Frontoparietals irregularly pentagonal, longer than wide (wider posteriorly), with a long medial suture; laterally in contact with third and fourth supraoculars; posteriorly in contact with interparietal and parietal. Interparietal pentagonal, lateral borders parallel to each other, about twice as long as wide. A pair of irregularly hexagonal parietals, slightly wider than, and longer than, interparietal; anteriorly in contact with fourth supraocular; laterally in contact with first and second supratemporals. The parietal and interparietals form an almost straight posterior head margin. Occipitals absent; two scales irregular in shape between the three scutes and anteriormost dorsal scales. Four supraoculars, anteriormost smallest, contacting frontal, prefrontal, loreal, first superciliary, and second supraocular. Second supraocular wider than long, contacting frontal, first and third supraoculars, and first and second superciliaries

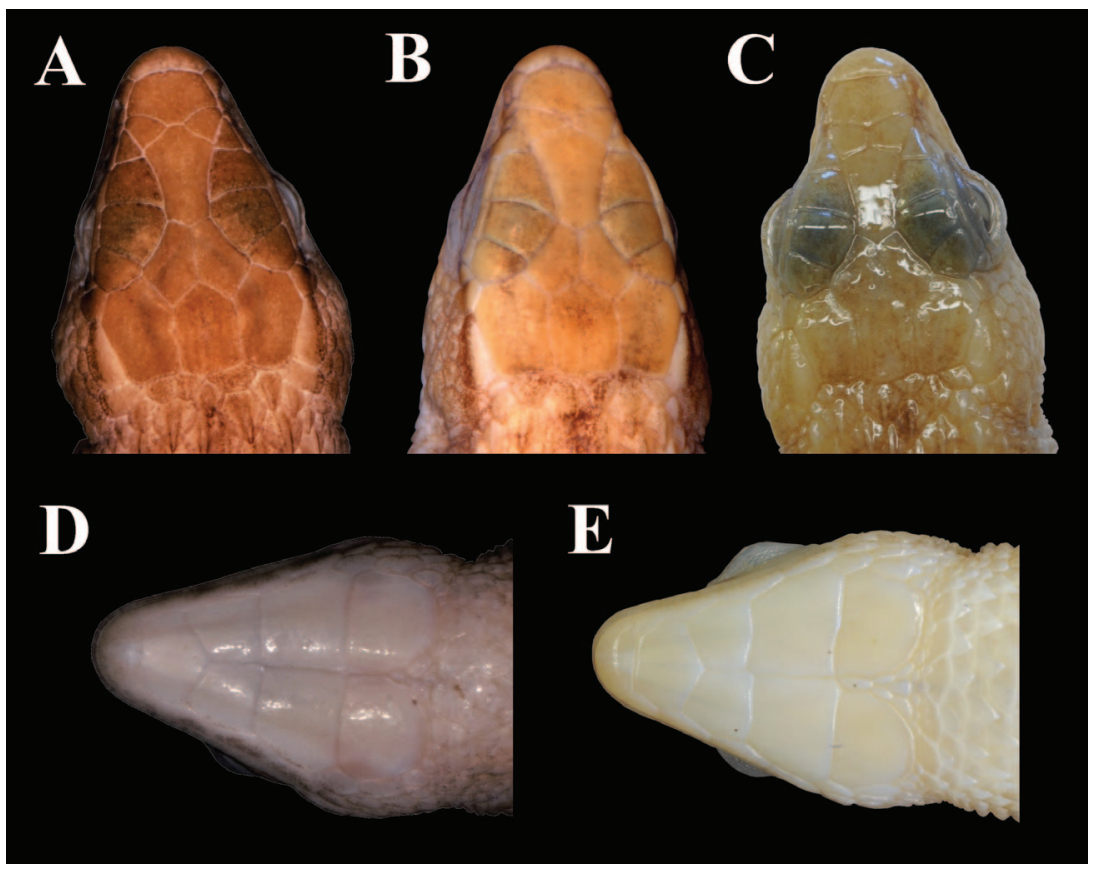

Fig. 5. Dorsal views of the head of the (A) paratype of Alopoglossus theodorusi sp. nov. (MNHN-RA-2020.0020), (B) paratype of Alopoglossus theodorusi sp. nov. (MNHN-RA-1996.4472), and (C) neotype of Alopoglossus angulatus (RMNH 15200); ventral views of the head of the (D) holotype of Alopoglossus theodorusi sp. nov. (MNHN-RA-2020.0019), and (C) neotype of Alopoglossus angulatus (RMNH 15200). 


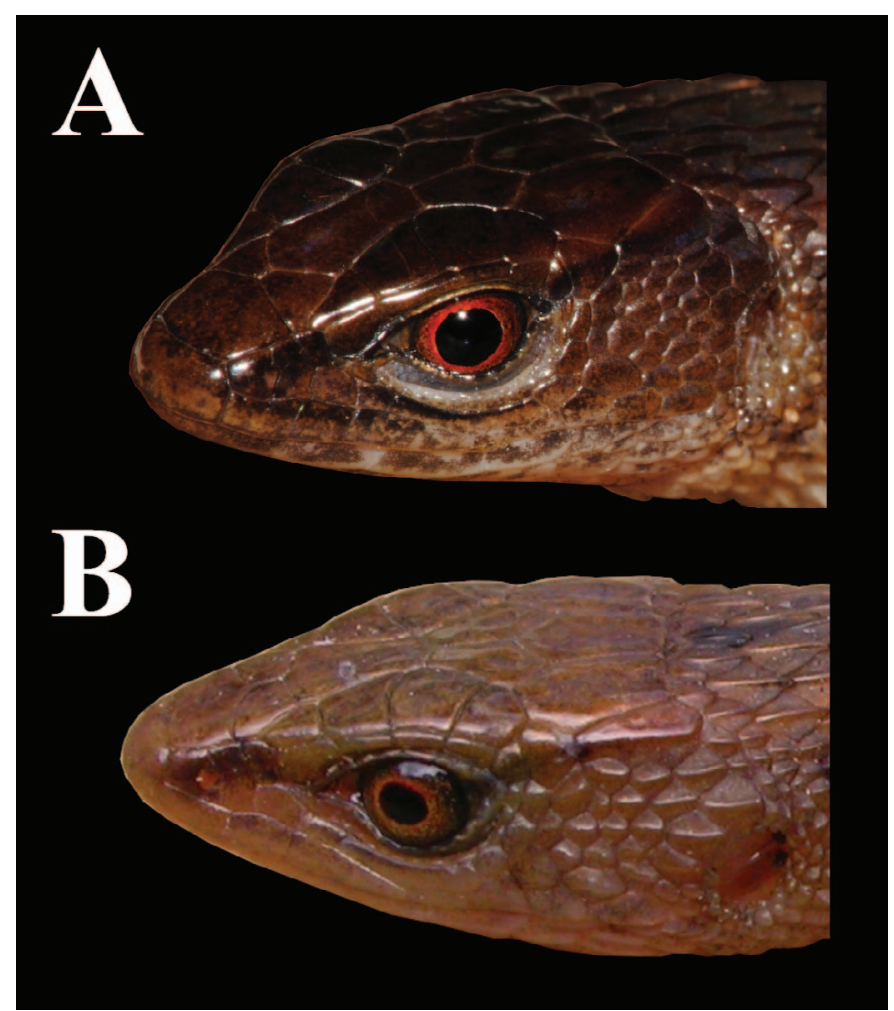

FIG. 6. Lateral views of the head of (A) Alopoglossus theodorusi sp. nov. from Lourenço, Amapá, Brazil (photo: Sergio Souza), and (B) Alopoglossus angulatus (MNHN-RA-2020.0028). (touching third superciliary on the right side). Third supraocular largest, as wide as long, contacting frontal, frontoparietal, second and fourth supraoculars, and third superciliary (also in contact with second superciliary on the left side). Fourth supraocular in contact with frontoparietal, parietal, third supraocular, third, fourth and fifth superciliaries, and first supratemporal. Five superciliaries; first four elongated; first tallest; second and third the longest; fifth irregularly trapezoidal (almost triangular). First superciliary (anteriormost) in contact with loreal, frenocular, first and second supraoculars, and second superciliary; second superciliary in contact with first and third superciliaries, second and third supraoculars on the left side, and third supraocular on the right side; third superciliary in contact with second and fourth superciliaries, third and fourth supraoculars on the left side, and second, third, and fourth supraoculars on the right side; fourth superciliary in contact with third and fifth superciliaries and fourth supraocular; fifth superciliary in contact with fourth superciliary, fourth supraocular, and first supratemporal. One elongated preocular scale between first superciliary, frenocular, and first subocular. Three suboculars; second longest, about three times longer than first and third suboculars; first longer than tall, contacting frenocular, second and third supralabials, and second subocular; second about six times longer than tall, contacting first and third suboculars, and third, fourth, and fifth supralabials; third as long as tall, contacting second subocular, fifth supralabial, and the lower postocular. Two postoculars continuous with third subocular; lower one almost quadrangular (as long as tall); upper one tallest (elongated dorsoventrally). A series of small granular scales above suboculars and preceding postoculars. Lower eyelid with semitransparent disc of three large

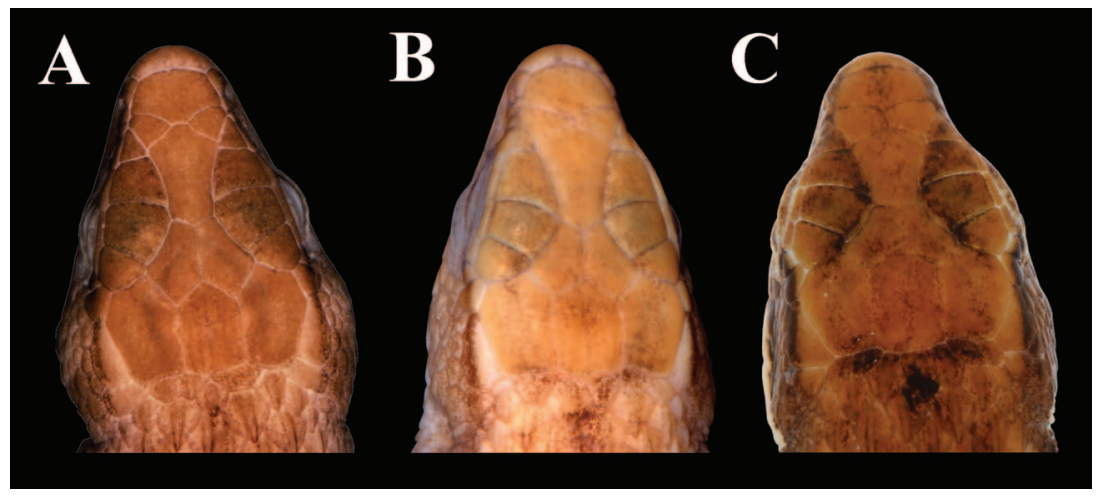

Fig. 7. Dorsal views of the head of the (A) paratype of Alopoglossus theodorusi sp. nov. (MNHN-RA-2020.0020), (B) paratype of Alopoglossus theodorusi sp. nov. (MNHN-RA-1996.4472), and (C) holotype of Alopoglossus avilapiresae (INPA-H 9515).

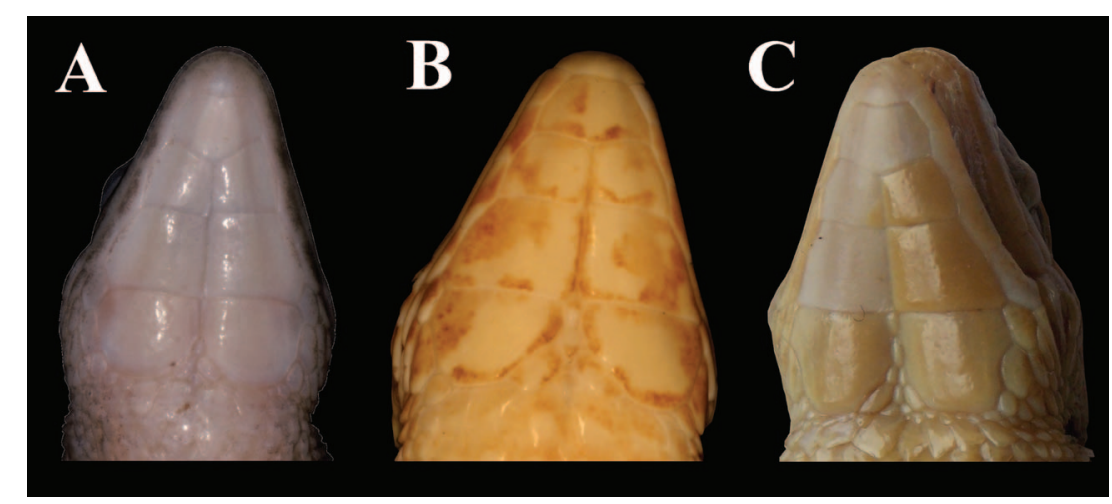

FiG. 8. Ventral views of the head of the (A) holotype of Alopoglossus theodorusi sp. nov. (MNHN-RA-2020.0019), (B) holotype of Alopoglossus andeanus (MCZ 45590), and (C) holotype of Alopoglossus carinicaudatus (ANSP 11371). 


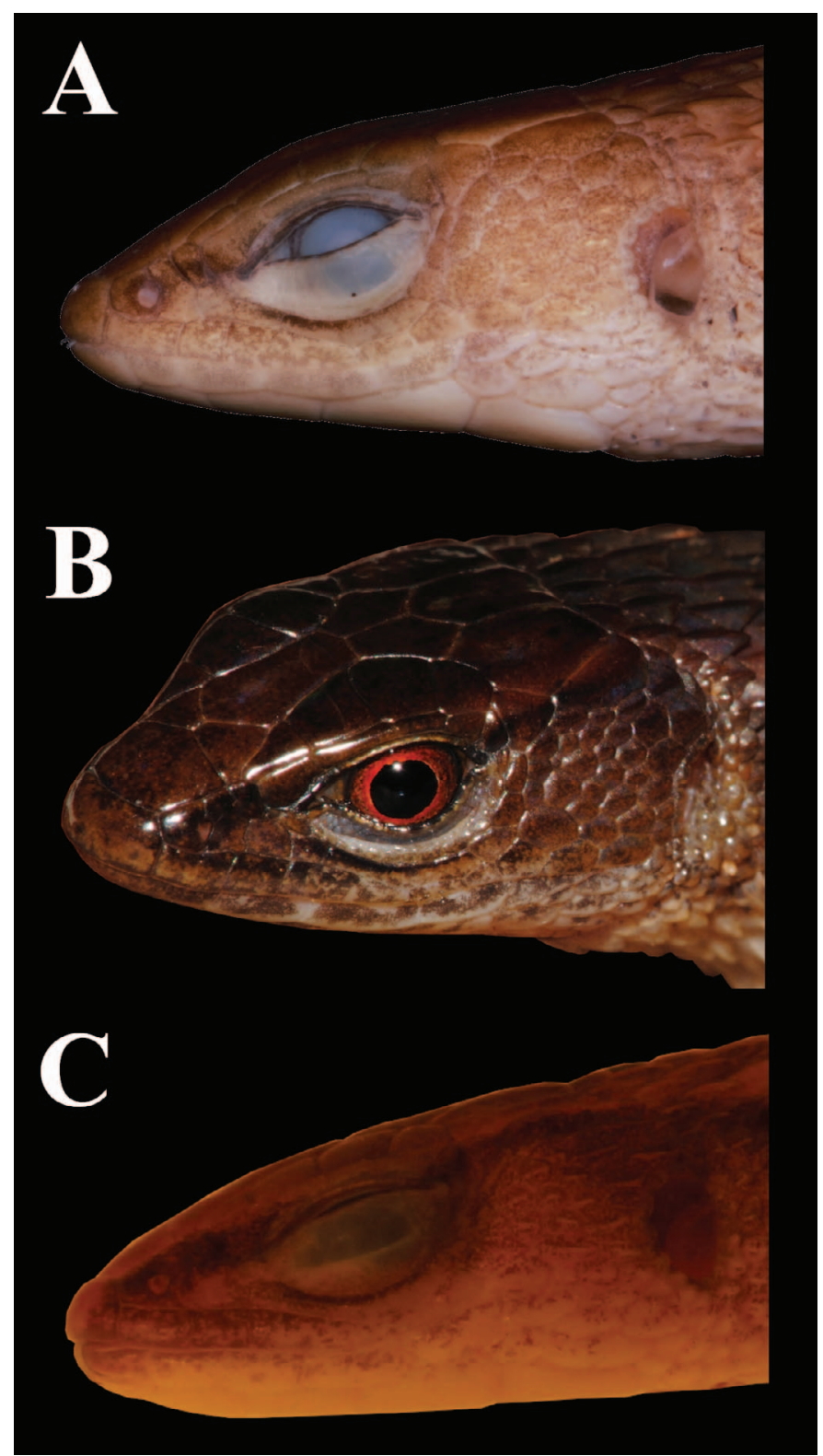

FIG. 9. Lateral views of the head of the (A) holotype of Alopoglossus theodorusi sp. nov. (MNHN-RA-2020.0019), (B) Alopoglossus theodorusi sp. nov. from Lourenço, Amapá, Brazil (photo: Sergio Souza), and (C) holotype of Alopoglossus collii (CHUNB 18038).

palpebrals on the right side, five on the left side. Nasal semidivided, irregularly pentagonal, longer than tall. Nostril in the median part of nasal, directed posterolaterally. Loreal rectangular, contacting nasal, prefrontal, first supraocular, first superciliary, and frenocular. Frenocular irregularly pentagonal, contacting loreal, nasal, second supralabial, first subocular, and preocular. Seven supralabials, third, fourth, and fifth under the orbital region, first four elongated; second and fifth the tallest; third the longest, about three times longer than tall. One postsupralabial. Temporals irregularly polygonal, juxtaposed; anterior ones smooth, and posterior ones on upper region feebly keeled. Two large supratemporal scales bordering on the parietal; first smooth, and second feebly keeled (general aspect smooth), largest. Ear-opening vertically oval, with anterior margin denticulate. Tympanum recessed into a short auditory meatus.
Except for posterior temporals on upper region, all dorsal and lateral head scales smooth and juxtaposed. Interparietal with lateral ridges.

Mental trapezoidal, about twice wider than long, with convex anterior margin. Postmental irregularly pentagonal, wider than long. Three pairs of chin shields, first two pairs in broad contact medially and with second, third, and fourth infralabials; scales of the third pair in contact anteriorly, but separated from each other by three small granular scales posteriorly, and separated from infralabials by larger scales laterally; third pair rounded medially and posteriorly, in direct contact with gulars. Six infralabials, all longer than tall; second, third, and fourth about twice as long as first; sixth smallest; suture between third and fourth below center of eye. Post-infralabials absent. Gulars smaller than dorsals, imbricate, differentiated in size toward collar; anteriormost transverse row with smooth scales, irregular in shape (varying from phylloid to almost rounded), with scales smaller than those on posterior rows; medial and posterior gular scales smooth, phylloid, feebly pointed, wider and longer than lateral gular scales; lateral gular scales phylloid, feebly pointed, varying from feebly keeled to strongly keeled; gular scales in nine transverse rows. Posterior row (collar) with nine smooth, feebly pointed, phylloid scales, varying from similar in size to slightly smaller than scales on preceding rows. No gular fold. Scales on nape similar in shape to, but slightly smaller than, dorsals. One transverse row of small granular scales posterior to ear-opening on the left side, and two rows on the right side. Scales on sides of neck distinctly smaller than dorsals, strongly keeled, imbricate, phylloid, in 10 transverse rows; anterior scales smaller than posterior ones. A distinctive area with scales much shorter than, but similar in shape to, neck scales, surrounds the area of arm insertion.

Dorsal scales rhomboid, strongly keeled and mucronate, imbricate and disposed in oblique rows; 28 scales along a middorsal line from parietals to the level of hind limbs. Scales on flanks similar to dorsals. Twenty-two scales around midbody. Ventral scales mucronate and imbricate; scales along the midventral portion smooth, anterior ones bluntly pointed, and posterior ones almost rounded; lateral ventral scales varying from smooth to feebly keeled and feebly pointed; 17 transverse rows and four longitudinal rows of ventral scales between collar and preanals. Eight scales in preanal plate, varying from smooth to feebly keeled; two largest scales on posteromedial region, two smallest scales on posterolateral region (one on each side), longer than wide, and four scales on anterior region; preanal plate is preceded by four scales irregular in size, but smaller than preceding ventral scales. Preanal and femoral pores absent (female).

Dorsal limb scales rhomboid, imbricate, sharply keeled, and mucronate; ventral limb scales varying from smooth to feebly keeled; ventral aspect of upper arms and posterior aspect of thighs with tuberculate scales. Five clawed digits on each limb. Lamellae under fingers single, transversely enlarged, and smooth, 15 under the fourth fingers; lamellae under toes divided, 19 under the fourth toes. Scales on tail keeled, slightly mucronate, imbricate, arranged in transverse (not counted) and in 12 longitudinal rows; scales in the two paravertebral rows wider than long near the base of the tail, and longer than wide in other rows. Keels mostly sharp on tail (except on anteriormost ventral rows, feebly keeled, almost rounded), forming four dorsal, two lateral (on each side), and four ventral distinct longitudinal ridges. 


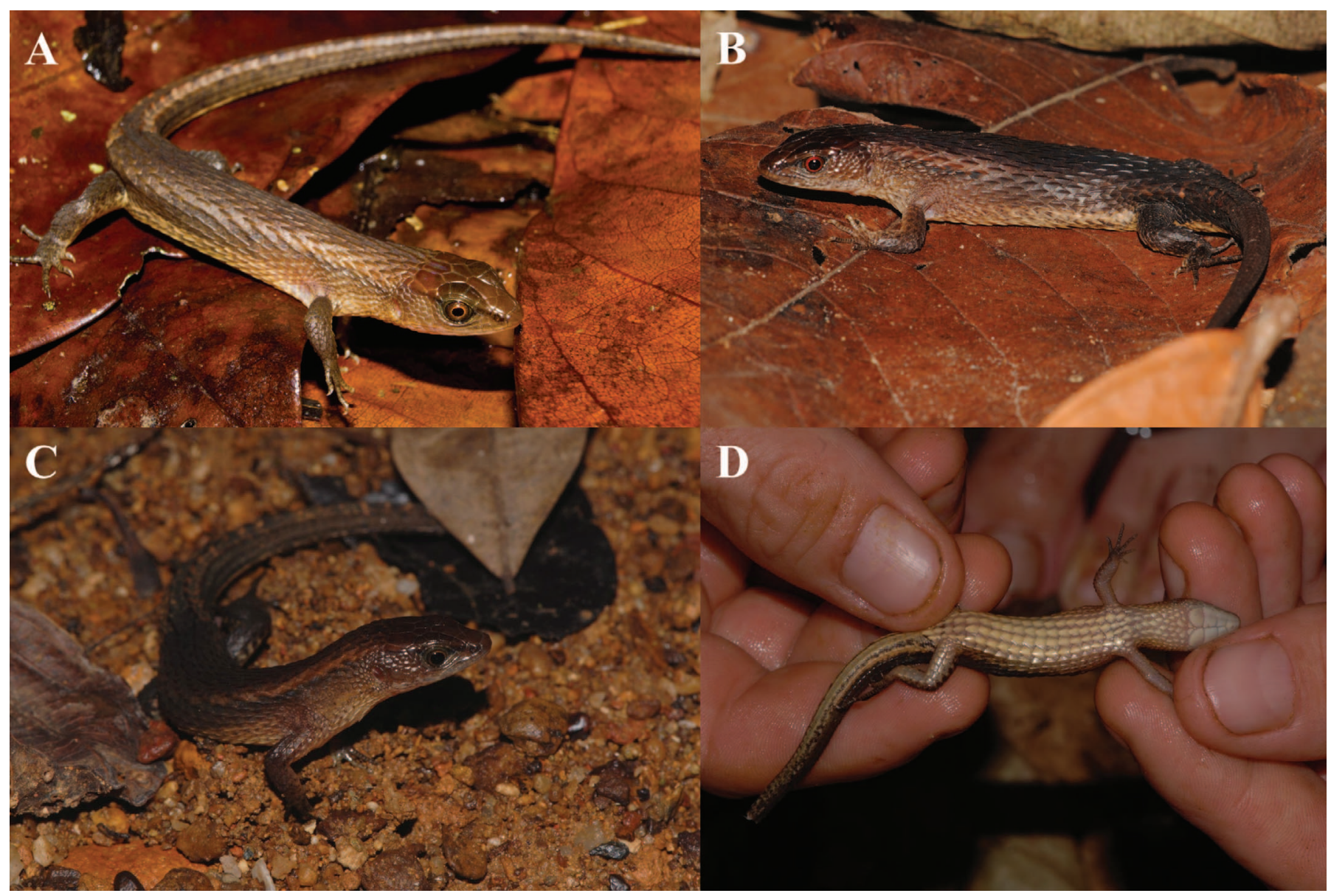

FIG. 10. Living specimen of Alopoglossus theodorusi sp. nov.: (A) holotype MNHN-RA-2020.0019, photo: Antoine Fouquet; (B) specimen from Lourenço, Amapá, Brazil, photo: Sergio Souza; (C) dorsal and (D) ventral views of specimen from Mont Belvedere, French Guiana, not collected, photos: Michel Blanc.

Measurements of holotype (mm): $\mathrm{SVL}=41.93 ; \mathrm{AGL}=19.76$; $\mathrm{HD}=5.19 ; \mathrm{HW}=7.27 ; \mathrm{HL}=9.37 ; \mathrm{NL}=7.1 ; \mathrm{FL}=12.3 ; \mathrm{HLL}=$ 20; $\mathrm{ShL}=6.54 ; \mathrm{TL}=69.37$.

Coloration in Preservative (based on holotype MNHN-RA2020.0019; Figs. 2, 3).-Dorsal surface of head, back, tail, and limbs light-brown; head and anterior surface of body homogeneously light-brown (head slithly darker than body); posterior surface of body and between the hind limbs with a few small dark-brown spots; dorsal tail cream, with a few dark-brown spots; dorsal limbs with a few small, irregular dark-brown spots. Lateral aspect of head and neck lighter than dorsal surface of body, becoming gradually cream ventrally; a rather inconspicuous dark-brown line extending posteriorly from the nostril, passing above ear opening and forelimbs, medially (and wider) on flanks, above hind limbs, and reaching laterally the tail; it is bordered dorsallly by a rather inconspicuous cream stripe from posterior corner of eye to tail; lateral surface of tail slightly darker than dorsal surface of tail. Ventral surface of head, body, and limbs homogeneously cream; preanal plate and ventral aspect of tail with a few small, irregular dark-brown spots.

Coloration in Life (based on photographs in life).- - Holotype, MNHN-RA-2020.0019 (Fig. 10A): Dorsal surface of head bright mahogany (supraoculars slightly darker than other head scales); dorsal surface of body and limbs dull mahogany, with sparse blackish spots on posterior body surface and on limbs; dorsal suface of tail dull amber, with orange, mahogany, and blackish spots along the tail, and a blackish band only on the anterior region. A dorsolateral amber stripe from posterior corner of eye to anterior surface of body. Lateral surface of head, neck, and anterior portion of the flanks dull amber; lateral surface of tail, limbs, and posterior portion of flanks dull mahogany, with blackish spots; lateral surface of head, body, limbs, and tail becoming gradually cream ventrally. A continuous bistre line extending from the nostril, around the eyes, above ear-opening, neck, shoulders, to posterior surface of body; wider on neck and shoulders; on anterior surface of body it is bordering the dorsolateral amber stripe ventrally. A rather inconspicuous ventrolateral cream line extending from the supralabials under the eye, passing through the lower part of ear-opening and neck, above the forelimbs, ventrolaterally on flanks, anterior and posterior surfaces of hind limbs (interrupted above hind limbs), to the tail. Iris vividly amber.

Photographed specimen from Lourenço, Amapá, Brazil (Fig. 10B) and specimen from Mont Belvedere, near Saul, French Guiana (Fig. 10C, 10D): Dorsal surface of head bright bistre; dorsal surface of body and limbs dull bistre; dorsal suface of tail dull mahogany, with orange, amber, and blackish spots along the tail, and a blackish band only on anterior region. A dorsolateral amber stripe from posterior corner of eye to anterior surface of body. Lateral surface of head, body (flanks), limbs, and tail dull bistre; neck dull mahogany; lateral surface of head, body, limbs, and tail becoming gradually cream ventrally. 
TABle 2. Summary of the variation in meristic characters and measurements between Alopoglossus amazonius, A. andeanus, A. angulatus, A. avilapiresae, A. carinicaudatus, A. collii, A. meloi, and $A$. theodorusi sp. nov. Counts and measurements are presented as minimum-maximum (mean \pm standard deviation); $n=$ total number of specimens studied. Counts for scales around the tail, number of loreal and frenocular scales presented similar ?4 values among specimens and species $(n=12 ; n=1 ; n=1$; respectively). Only intact and nonregenerated tails were considered. $-=$

\begin{tabular}{|c|c|c|c|}
\hline Meristics & A. amazonius $(n=28)$ & A. andeanus $(n=6)$ & A. angulatus $(n=217)$ \\
\hline Dorsals & $25-31(27.8 \pm 1.5)$ & $27-30(28.7 \pm 1)$ & $22-29(26 \pm 1.8)$ \\
\hline Ventrals & $16-19(17 \pm 0.8)$ & $15-20(16.8 \pm 1.8)$ & $14-18(16.3 \pm 1)$ \\
\hline Midbody & $19-22(20.7 \pm 1.1)$ & $19-20(19.7 \pm 0.5)$ & $18-22(20.1 \pm 0.7)$ \\
\hline Supraoculars & 4 & 4 & $4-5(4 \pm 0.2)$ \\
\hline Superciliaries & $5-6(5.1 \pm 0.3)$ & 5 & $4-5(5 \pm 0.1)$ \\
\hline Suboculars & 3 & $3-4(3.2 \pm 0.4)$ & $3-4(3 \pm 0.1)$ \\
\hline Postoculars & $1-3(2.3 \pm 0.7)$ & $2-3(2.7 \pm 0.5)$ & $1-2(1.9 \pm 0.3)$ \\
\hline Supralabials & 7 & 7 & 7 \\
\hline Infralabials & 6 & 6 & 6 \\
\hline Scales on sides of neck & $9-13(11.8 \pm 0.7)$ & $11-12(11.3 \pm 0.5)$ & $6-9(8.4 \pm 0.6)$ \\
\hline Pairs of chin shields & 4 & 3 & 3 \\
\hline Scales between 3rd pair of chin shields & $1-4(2.2 \pm 0.8)$ & $4-8(5.8 \pm 1.5)$ & $1-13(5.3 \pm 1.9)$ \\
\hline Scales between 4 th pair of chin shields & $0-5(2.4 \pm 1.6)$ & $3-7$ between pregular scales $(4.7 \pm 1.5)$ & - \\
\hline Gulars & $7-10(8.7 \pm 0.8)$ & $7-9(8.2 \pm 0.8)$ & $7-10(8.6 \pm 0.7)$ \\
\hline Lamellae under 4 th finger & $13-16(14 . \overline{8} \pm 1)$ & $13-17(14.8 \pm 1.8)$ & $11-16(13.9 \pm 1.3)$ \\
\hline Lamellae under 4 th toe & $17-23(20.7 \pm 1.5)$ & $17-21(19.7 \pm 1.8)$ & $14-23(19.2 \pm 1.6)$ \\
\hline Femoral pores in males & $24-28(25.5 \pm 1.9)$ & $24-28(25.7 \pm 2.1)$ & $20-29(24.2 \pm 1.7)$ \\
\hline Measurements (mm) & A. amazonius $(n=12)$ & A. andeanus $(n=3)$ & A. angulatus $(n=82)$ \\
\hline Snout-vent length & $34.6-62(51.2 \pm 9$. & $40.3-58(46.6 \pm 9.9)$ & $37.6-60.5(49.3 \pm 5.1)$ \\
\hline Axilla-groin length & $16.6-30.7(25.2 \pm 5.2)$ & $18.3-29(22.7 \pm 5.6)$ & $15.2-28.8(22.1 \pm 3.2)$ \\
\hline Head depth & $4.1-7.5(6 \pm 1.1)$ & $5.4-7.7(6.2 \pm 1.3)$ & $4.5-7.8(5.9 \pm 0.8)$ \\
\hline Head width & $5.2-9.8(8.2 \pm 1.6)$ & $6.4-10.5(7.9 \pm 2.3)$ & $5.7-9.9(7.5 \pm 0.9)$ \\
\hline Head length & $7.7-13.5(10.9 \pm 1.6)$ & $9.1-13.8(11 \pm 2.5)$ & $9.1-13.1(10.9 \pm 0.9)$ \\
\hline Neck length & $5.1-9.6(7.5 \pm 1.6)$ & $5.6-9(7.4 \pm 1.7)$ & $4.9-9.8(7.3 \pm 0.9)$ \\
\hline Forelimb length & $8.8-17(13.9 \pm 2.6)$ & $8.8-16.5(11 . \overline{7} \pm 4.2)$ & $8.4-16.3(13.1 \pm 1.6)$ \\
\hline Hind limb length & $15.4-27(22.8 \pm 4.1)$ & $12.7-29.5(18.6 \pm 9.4)$ & $14.3-27.2(21.5 \pm 2.4)$ \\
\hline Shank length & $5.2-7.8(6.5 \pm 0.8)$ & $6.2-6.8(6.5 \pm 0.3)$ & $4.5-10.1(7.6 \pm 0.9)$ \\
\hline Tail length & $\begin{array}{c}57.3-82.3 \\
(76.9 \stackrel{ \pm}{ \pm} 16.6 ; n=8)\end{array}$ & - & $\begin{array}{c}58-106.9 \\
(81.9 \stackrel{ \pm 9.6 ;}{ \pm}=52)\end{array}$ \\
\hline
\end{tabular}

A continuous blackish line extending from the nostril, around the eyes, above ear-opening, neck, shoulders, to posterior surface of body; wider on flanks; on anterior surface of body it is bordering the dorsolateral amber stripe ventrally. A rather inconspicuous ventrolateral cream line extending from the supralabials under the eye, passing through the lower part of ear-opening and neck, ventrolaterally on flanks, anterior and posterior surfaces of hind limbs (interrupted above the limbs), to the tail. Ventral surface description only from the specimen from Mont Belvedere, French Guiana (Fig. 10D): head, body, limbs, and tail bright cream; preanal plate with sparse blackish spots; tail with a ventrolateral bistre line, bordered ventrally by an inconspicuous blackish stripe on anterior region. Iris vividly amber.

Variation in Meristic Characters.-There is little variation in meristic characters among specimens. MNHN-RA-2020.0021 has three postoculars; MNHN-RA-1996.4471 has four subocular scales; and MNHN-RA-1996.4473 has prefrontals smaller than on other species, and widely separated from each other. Prefrontals on MNHN-RA-1996.4471-72 (both males) are in narrow contact with each other, while on all other specimes they are separated by the contact between frontonasal and frontal. All males have a total number of 22 femoral pores. Variation in coloration in preservative: a few specimens have, from nape and along the middorsal, a median series of dark brown spots, which merge between the hind limbs and the base of tail to form a dark brown band; posteriad this level, alternated dark brown and cream bands along the tail. Variation in coloration in life was presented above. Table 2 presents a summary of the variation (maximum and minimum values, average and standart deviation) of meristic characters and measurements, compared with all other species of the $A$. angulatus group.

Etymology.-The specific epithet is a noun in the genitive case honoring herpetologist Theodorus Willem van Lidth de Jeude, in recognition of his valuable contribution to the knowledge of the reptiles, especially from the Guiana Shield and Caribbean Islands.

Distribution and Habitat.-Alopoglossus theodorusi is distributed in the easternmost part of the Guiana Shield, in French Guiana and Amapa state, Brazil (Fig. 11). This species is likely endemic to that region along many other species of squamates and anurans (see below). Very little information is available about the ecology of the species. Nevertheless, specimens were found either at night or during the day but always along the banks of clear water streams in pristine rainforest.

Remarks.-Variation among specimens of A. theodorusi related to the contact or not between prefrontals seems to be a sign of sexual dimorphism. All female specimens $(n=3)$ have prefrontals separated from each other by the contact between frontonasal and frontal, while three of the four males have prefrontals with short contact between each other (Fig. $5 \mathrm{~A}, 5 \mathrm{~B})$. Both males and females of the sympatric species $A$. angulatus have prefrontals in contact with each other; however, the suture formed by the contact is distinctly longer than the 
TABLE 2. Extended.

\begin{tabular}{|c|c|c|c|c|}
\hline A. avilapiresae $(n=64)$ & A. carinicaudatus $(n=7)$ & A. collii $(n=9)$ & A. meloi $(n=23)$ & $\begin{array}{l}\text { A. theodorusi sp. nov. } \\
\qquad(n=6)\end{array}$ \\
\hline $23-30(27.7 \pm 1.7)$ & $22-27(25.3 \pm 1.8)$ & $26-29(27.2 \pm 1.3)$ & $24-28(25.8 \pm 1.4)$ & $25-28(26.2 \pm 1)$ \\
\hline $14-18(16.3=$ & $15-17(15.6 \pm 0.8)$ & $18-19(18.3 \pm 0.5)$ & $15-18(15.9 \pm 1)$ & $16-17(16.8 \pm 0.4)$ \\
\hline $19-22(20.6 \pm 0.8)$ & $15-21(18.4 \pm 2.5)$ & $19-21(20.2 \pm 0.8)$ & $19-21(20.2 \pm 0.8)$ & $20-22(21 \pm 0.9)$ \\
\hline 4 & 4 & 4 & $4-5(4.04 \pm 0.2)$ & 4 \\
\hline $4-5(5 \pm 0.2)$ & 5 & 5 & $5-7(5.08 \pm 0.4)$ & 5 \\
\hline $2-3(3 \pm 0.2)$ & $2-4(3 \pm 0.6)$ & 3 & 3 & $3-4(3.2 \pm 0.4)$ \\
\hline $2-3(2.3 \pm 0.5)$ & $2-3(2.4 \pm 0.5)$ & $1-3(2 \pm 0.7)$ & $1-3(2 \pm 0.5)$ & $2-3(2.2 \pm 0.4)$ \\
\hline $7-8(7.1 \pm 0.3)$ & 7 & 7 & $7-8(7.5 \pm 0.5)$ & 7 \\
\hline $6-7(6 \pm 0.2)$ & 6 & 6 & 6 & 6 \\
\hline $10-13(11.4 \pm 0.8)$ & $11-12(11.4 \pm 0.5)$ & $8-9(8.2 \pm 0.4)$ & $6-8(7.3 \pm 0.6)$ & $9-10(9.7 \pm 0.5)$ \\
\hline & & 3 & & \\
\hline $1-7(4.2 \pm 1.9)$ & $4-9(5.9 \pm 2)$ & $1-6(2.8 \pm 2)$ & $0-3(1.3 \pm 0.6)$ & $2-6(2.8 \pm 0.7)$ \\
\hline & & $0-2 *$ between pregular scales & $0-2(0.5 \pm 0.7)$ & \\
\hline $7-10(8.6 \pm 0.8)$ & $7-10(8.1 \pm 1.1)$ & $9-10(9.3 \pm 0.5)$ & $7-9(8 \pm 0.3)$ & $7-9(8.2 \pm 0.7)$ \\
\hline $12-18(14.3 \pm 1.3)$ & $12-16(14.6 \pm 1.6)$ & $12-14(13.1 \pm 0.8)$ & $14-16(14.9 \pm 0.9)$ & $13-15(14 \pm 0.9)$ \\
\hline $17-23(19.9 \pm 1.6)$ & $20-23(21.9 \pm 1.1)$ & $18-23(20.8 \pm 1.5)$ & $18-23(20.8 \pm 1.4)$ & $19-23(21.5 \pm 1.8)$ \\
\hline $23-29(25.7 \pm 1.7)$ & $22-26(24.6 \pm 1.7)$ & $19-22(21.2 \pm 0.7)$ & $20-23(21.7 \pm 1.3)$ & 22 \\
\hline A. avilapiresae $(n=26)$ & A. carinicaudatus $(n=7)$ & A. collii $(n=5)$ & A. meloi $(n=6)$ & $\begin{array}{l}\text { A. theodorusi sp. nov. } \\
\qquad(n=6)\end{array}$ \\
\hline $36.1-58.7(50 \pm 7)$ & $33.5-58.9(47.7 \pm 8.3)$ & $40-52.5(48$ & $38.6-57.2($ & $33.8-59.6(44.8 \pm 8.8)$ \\
\hline $14.7-30.4(23.3 \pm 4.3)$ & $15.2-30.1(23.1 \pm 4.7)$ & $19.2-24.9(22.3 \pm 2.4)$ & $16.4-27.8(20.3 \pm 4.1)$ & $15.3-28.1(21.6 \pm 4.5)$ \\
\hline $4.4-7.1(6 \pm 0.7)$ & $4.8-6.5(5.5 \pm 0.6)$ & $4.9-7.5(6.3 \pm 1.1)$ & $5-7.1(5.9 \pm 0.7)$ & $5-6.2(5.4 \pm 0.4)$ \\
\hline $5.8-9.4(7.7 \pm 0.9)$ & $5.9-8.7(7.7 \pm 1.1)$ & $7.6-9.4(8.4 \pm 0.7)$ & $6.2-9.5(7.2 \pm 1.2)$ & $6-9.1(7.4 \pm 1)$ \\
\hline $8.5-13.3(11 \pm 1.3)$ & $8.1-12.1(10.4 \pm 1.4)$ & $8.4-11.5(9.6 \pm 1.3)$ & $8.6-12.5(10.5 \pm 1.4)$ & $7.8-11.5(9.5 \pm 1.2)$ \\
\hline $5.4-9.8(7.5 \pm 1)$ & $5.9-9.3(7.4 \pm 1.2)$ & $5-9(7.7 \pm 1.6)$ & $5.7-11.5(7.5 \pm 2.2)$ & $5-8.8(7.1 \pm 1.2)$ \\
\hline $6.7-18.8(11.9 \pm 2.7)$ & $6.4-17.3(13.3 \pm 4.3)$ & $12.3-15.9(14.4 \pm 1.5)$ & $10.5-17.5(12.6 \pm 2.6)$ & $10.1-15.5(12.9 \pm 2)$ \\
\hline $11.2-25.5(18.6 \pm 4.8)$ & $10.1-28.7(21.5 \pm 7.2)$ & $18.5-23(20.3 \pm 1.9)$ & $16.3-32.2(21.6 \pm 5.9)$ & $16.4-25.2(20.3 \pm 3.1)$ \\
\hline 5.4-8.7 (7.2 \pm 1$)$ & $4.9-8.4(6.7 \pm 1.1)$ & $5.4-6.3(6 \pm 0.4)$ & $6.3-10.7(7.7 \pm 1.7)$ & $5.5-7.9(6.7 \pm 0.8)$ \\
\hline 50.3-97 & $54.9-76.5$ & $74.2-99.8$ & $71.5-97$ & $69.4(n=1)$ \\
\hline & & & & \\
\hline
\end{tabular}

suture formed in males of $A$. theodorusi (Fig. 5-C). Hoogmoed (1973: 221) commented that all specimens of A. angulatus examined by him from Suriname have a "short median suture between prefrontals." Our comparisons among specimens of $A$. angulatus and $A$. theodorusi, including specimens from Suriname, suggests that Hoogmoed's categorization of the sutures as long or short may have been based on comparisons between different species of lizards and does not reflect categorization considering only Alopoglossid. Ávila-Pires (1995:309) mentioned one Alopoglossus specimen (KU 127245) with prefrontals narrowly separated from each other, from Belém, Brazil. Köhler et al. (2012:176; fig. 3) also presented one specimen from Itaituba, Brazil, with prefrontals separated from each other by the contact between frontonasal and frontal. We examined specimens from Belém and Itaituba housed at the herpetological collection of the Museu Paraense Emílio Goeldi, and even though these specimens have prefrontals separated from each other, we diagnosed them as $A$. angulatus based on the combination of all diagnostic characters for this species (Ribeiro-Júnior et al., 2020). The population from Itaituba was also recovered as A. angulatus by molecular analysis in Ribeiro-Júnior et al. (2020). In some cases the contact between prefrontal scales in A. avilapiresae could be difficult to categorize as long or short (in some specimens the scales are even separated). In such cases, identification to $A$. theodorusi or A. avilapiresae should be based on the contact between scales of the third pair of chin shields (always in contact in A. theodorusi; separated in A. avilapiresae), the number of transverse rows of scales on sides of neck (9-10 in A. theodorusi vs. 10-13 in A. avilapiresae), and number of femoral pores in males (22 in A. theodorusi vs. 23-29 in $A$. avilapiresae) to reach a correct identification.

The Taxonomic Status of Alopoglossus copii surinamensis.Alopoglossus copii surinamensis, described by Brongersma (1946), was placed under synonym of $A$. angulatus by Ruibal (1952) and, despite taxonomic revisions and descriptions of new species and resurrections in the genus (Duellman, 1973; Ayala and Harris, 1984; Ávila-Pires, 1995; Köhler et al., 2012; Peloso and Morales, 2017; Ribeiro-Júnior, 2018; Ribeiro-Júnior et al., 2020), Brongersma's specimen and Ruibal's action had been revised. In addition, we needed to verify that "Alopoglossus angulatus French Guiana lineage", here described as $A$. theodorusi, is not in fact $A$. copii surinamensis. Thus, we examined the specimen RMNH.RENA.4858, collected on 2 December 1910 by K. Hulk, at forest on the Lucie River (holotype of A. copii surinamensis; Figs. 12, 13), housed in the Naturalis Biodiversity Center, Leiden, The Netherlands. The specimen has prefrontal scales in contact with each other medially, forming a long suture between them; temporal scales strongly keeled; scales on sides of neck in eight transverse rows; and third pair of chin shields completely separated from each other by 12 granular scales, and separated from gulars by a row of small scales (Fig. 13). Therefore, this specimen fits exactly the diagnosis of $A$. angulatus, which 

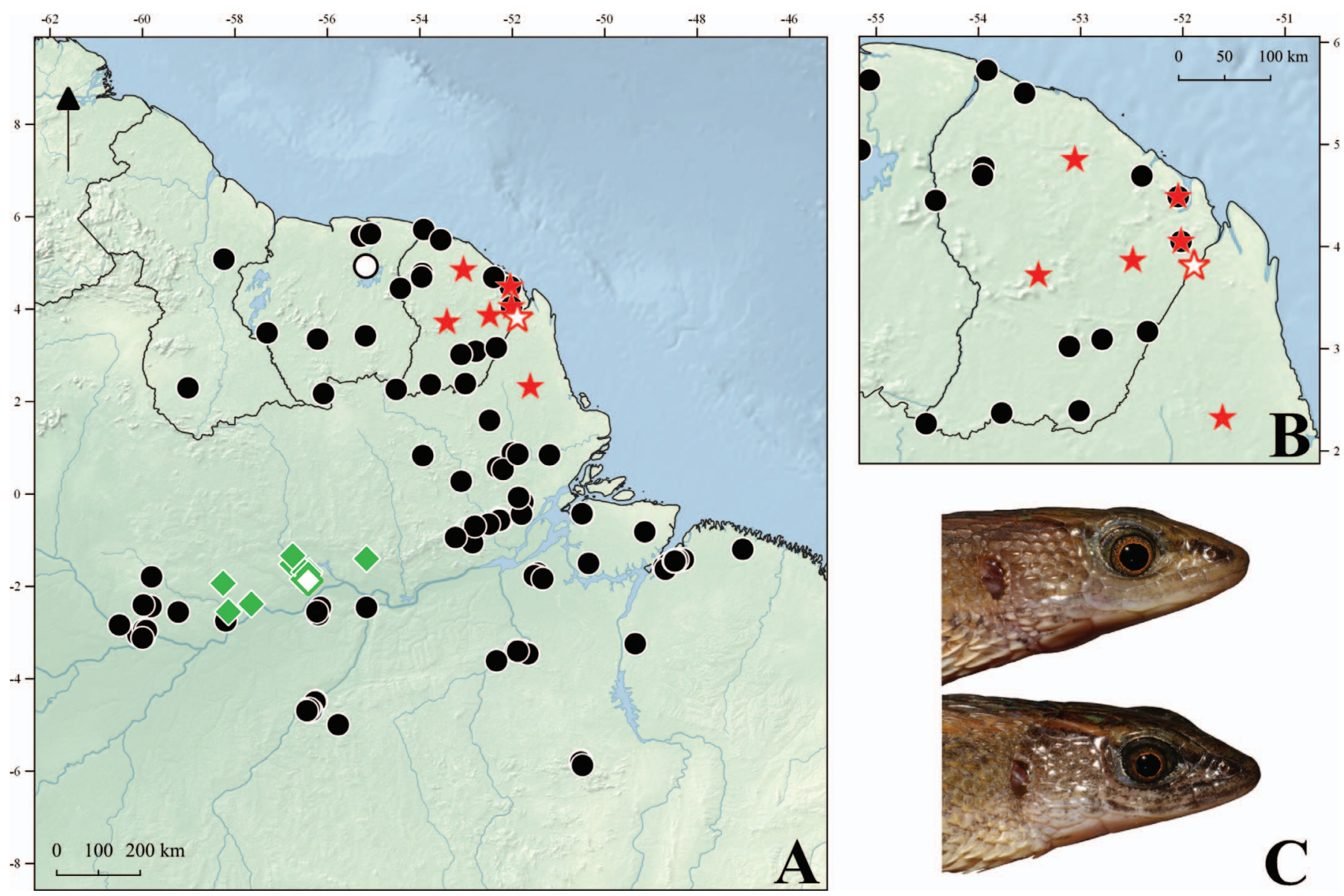

Fig. 11. (A) Distributional records of eastern Amazonian species of Alopoglossus (black dots: A. angulatus; green diamonds: A. meloi; red stars: A theodorusi; white symbols: type-localities); (B) distributional records of $A$. theodorusi in French Guiana and Amapa State, Brazil; (C) living specimens of Alopoglossus angulatus (above) and A. theodorusi (below), both from Mont Galbao, French Guiana, photos: Mael Dewynter \& Elodie Courtois. *Note differences on temporal scales (Alopoglossus angulatus, strongly keeled aspect; $A$. theodorusi, smooth general aspect).

confirms Ruibal's taxonomic action in placing it in synonymy of A. angulatus.

\section{DiscusSion}

Alopoglossus theodorusi adds up to the 46 nominal species of native lizard already known to occur in French Guiana (Dewynter et al., 2020) and 143 species in the Brazilian Amazonia (Ribeiro-Júnior and Amaral, 2016b, 2017). The discovery of a new lizard in Amazonia is not surprising because new species descriptions of squamates and anurans keep accumulating rapidly (França and Venâncio, 2010). In fact, almost all systematic investigation of any largely distributed group in Amazonia leads to the understanding that they actually represent species complexes often hiding narrowly distributed species within Amazonia (e.g., Nunes et al., 2012; Fouquet et al., 2014; Ribeiro-Júnior, 2015a; Ribeiro-Júnior and Amaral, 2016a, 2017; Passos et al., 2017; Silva et al., 2018; Ribeiro-Júnior et al., 2020; Vacher et al., 2020). This is the case of A. theodorusi, which is probably endemic to the easternmost part of the Guiana Shield and was so far confused with $A$. angulatus. A similar situation has been unraveled in many other squamate clades, such as Iphisa elegans (Nunes et al., 2012), Cercosaura ocellata (Ribeiro-Júnior and Amaral, 2017), Neusticurus rudis (Kok et al., 2018), and Atractus flammigerus (Passos et al., 2017). This pattern may in fact be as prevalent as in anurans (Vacher et al., 2020) and, consequently, regional endemism notably in the lowlands of the Guiana Shield is likely much underestimated for squamates as well (e.g., Ribeiro-Júnior and Amaral, 2016b presented five new taxa endemic to the region just awaiting formal descriptions).

Currently, nine forest lizards $(9 / 39=23 \%)$ are considered endemics to the lowlands of the Guiana Shield (Anolis chrysolepis, A. phylopunctatus, Gonatodes annularis, Coleodactylus septentrionalis, Amapasaurus tetradactylus, Arthrosaura versteegi, Bachia remota, Neusticurus surinamensis, Panopa carvalhoi; RibeiroJúnior, 2015a, 2015b; Ribeiro-Júnior and Amaral, 2016a, 2017), and among them only Bachia remota and Alopoglossus theodorusi seem to be restricted to the easternmost part of the Guiana Shield lowlands. This is in striking contrast with anurans in which more than $80 \%$ of the species occurring in the Guiana Shield lowlands are assumed to be endemics and where the easternmost part of of this region stands as distinct in terms of species composition (Vacher et al., 2020). We assume that this discrepancy is at least partly because of the lack of investigations combining molecular and morphological methods with fine-scaled sampling of populations encompassing the Guiana Shield lowlands, such as in Tretioscincus agilis, Arthrosaura kockii, A. reticulata, and Bachia flavescens. As a matter of fact, RibeiroJúnior and Amaral (2017) identified a still undescribed 


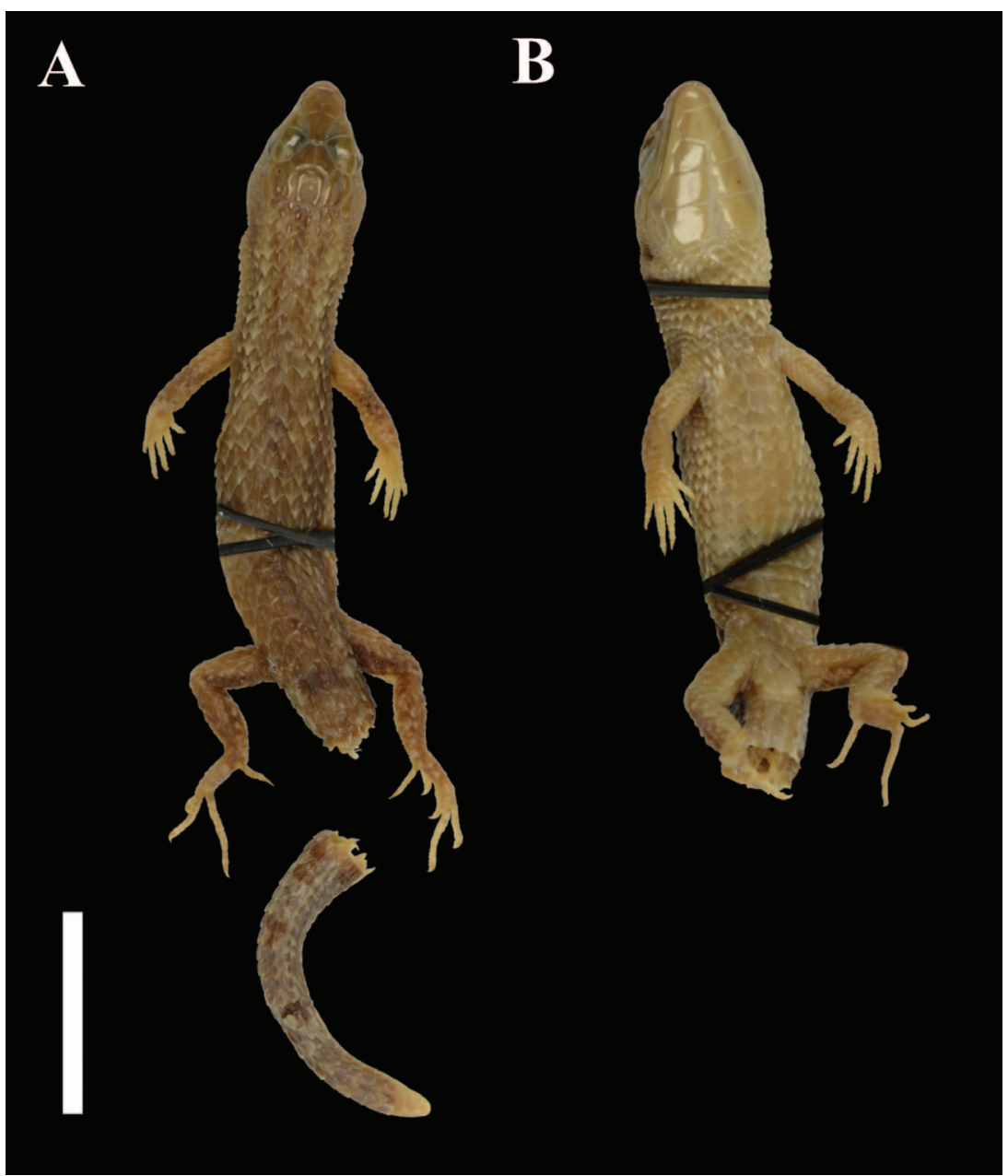

Fig. 12. (A) Dorsal and (B) ventral views of the holotype of Alopoglossus copii surinamensis (RMNH.RENA.4858). Scale bar $=1 \mathrm{~cm}$.

Cercosaura, which dispays a strikingly similar distribution to the one of A. theodorusi.

A combination of historical and contemporary climatic heterogeneity as well as low dispersal ability and narrow niches of these endemic species could explain these narrow ranges (Vacher et al., 2020). The climate of the easternmost part of the Guiana Shield has high rainfall, which decreases westwards. Alopoglossus theodorusi is associated with riparian forests along small streams. Even though this remains speculative given the limited amount of ecological data available, we assume that the species is associated with stable fresh and wet microclimatic conditions that probably restrict its dispersal and circumscribe its range.

Acknowledgments.-We thank the following curators and personnel from museums who granted access to specimens: N. Vidal (Muséum National D'Histoire Naturelle de Paris), E. Dondorp (Naturalis Biodiversity Center), P. Venegas (Centro de Ornitología y Biodiversidad, Lima), D. Frost, D. Kizirian (American Museum of Natural History), J. Losos (Harvard Museum of Comparative Zoology), R. Heyer, K. Tighe (Smithsonian Institution), H. Zaher, C. Castro-Mello (Museu de Zoologia da Universidade de São Paulo), G. Colli, I. Arantes (Universidade de Brasília), R. Vogt, F. Werneck, A. Silva, V. Carvalho, R. Fraga, A. Lima (Instituto Nacional de Pesquisas da
Amazônia), T. Ávila-Pires, A. Prudente, F. Sarmento (Museu Paraense Emílio Goeldi), S. Morato, J. Moura-Leite (Museu de História Natural do Capão da Imbuia), M. Menin (Universidade Federal do Amazonas), J. D. Lima and J. R. Lima (Instituto de Pesquisas Científicas e Tecnológicas do Estado do Amapá); and the curators and personnel from museums who helped with photographs of holotypes and neotype: E. Dondorp (Alopoglossus angulatus, A. copii surinamensis, Naturalis Biodiversity Center) and A. Dourado (A. avilapiresae, Instituto Nacional de Pesquisas da Amazônia; A. meloi, Museu Paraense Emílio Goeldi); and N. Vidal for the loan of specimens and for accepting the deposition of material in the collection of the MNHN. We also thank Q. Martinez, E. Courtois, M. Dewynter, P. Gaucher, M. Blanc, S. Souza, and J. Lima for providing specimens and their help in the field; and M. Silva for sending photographs of a few specimens housed in MPEG. This work was supported by Ministério da Ciência e Tecnologia, Conselho Nacional de Desenvolvimento Científico e Tecnológico [CTINFRA/GEOMA 61/2009], the Conselho Nacional de Desenvolvimento Científico e Tecnológico [CNPq 475559/2013-4], the Agence Nationale de la Recherche ("Investissement d'Avenir") [CEBA, ref. ANR-10-LABX-25-01], the Gans Collections and Charitable Fund Inc. (grant), the Rector scholarship (Tel Aviv University; MAR-J postdoctoral fellowship), and the Alexander and Eva Lester Fund scholarship (I. Meier Segals Garden for 


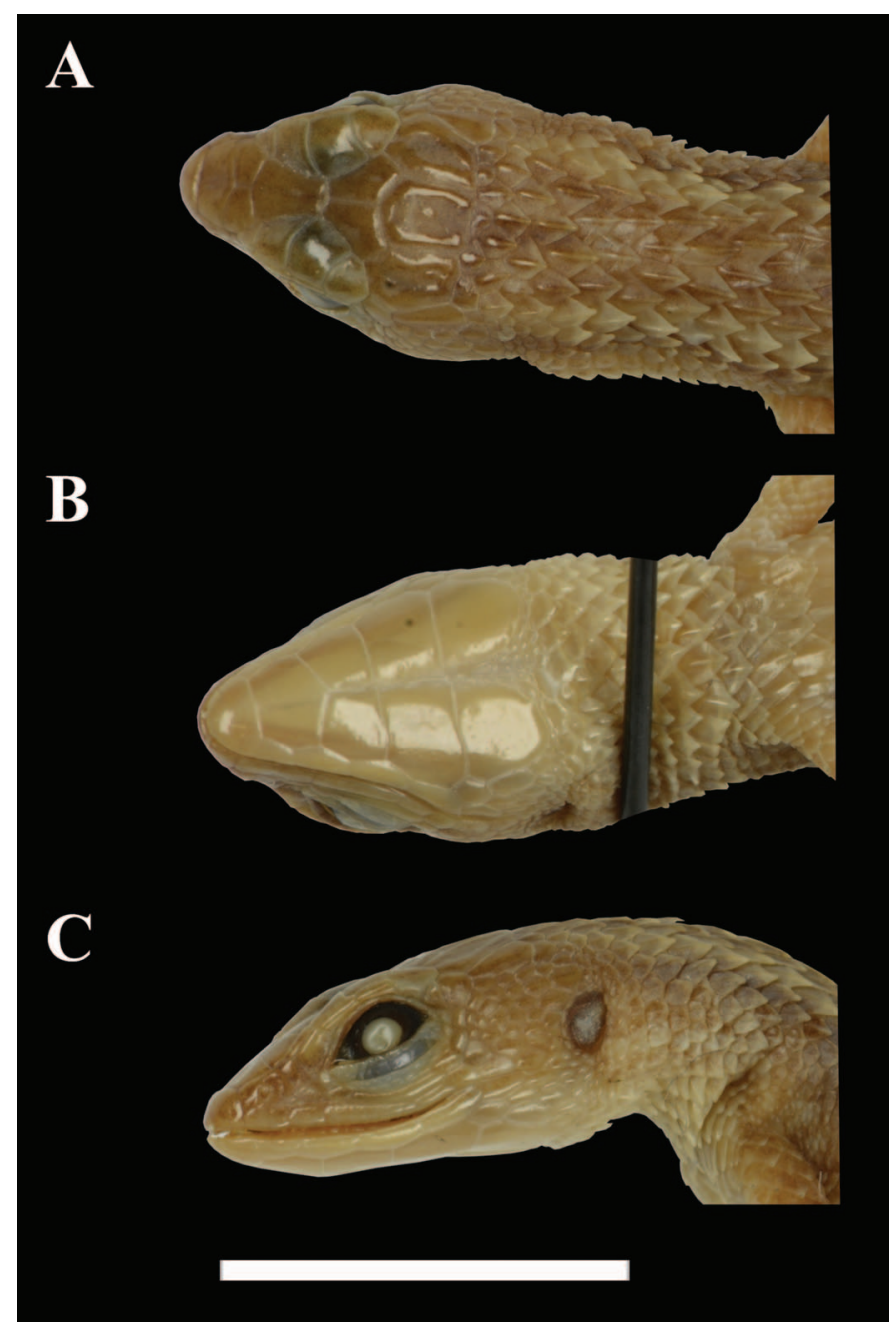

FIG. 13. (A) Dorsal, (B) ventral, and (C) lateral views of the head and neck of the holotype of Alopoglossus copii surinamensis (RMNH.RENA. 4858). Scale bar $=1 \mathrm{~cm}$.

Zoological Research; MAR-J postdoctoral fellowship). We also thank two anonymous reviewers and Matthew P. Heinicke for their valuable contributions in improving our study.

\section{Literature Cited}

Ávila-PIRES, T. C. S. 1995. Lizards of Brazilian Amazonia (Reptilia: Squamata). Zoologische Verhandelingen 299:1-706.

AyalA, S. C., AND D. M. HARRIS. 1984. A new microteiid lizard (Alopoglossus) from the Pacific rain forest of Colombia. Herpetologica 40:154-158.

Boulenger, G. A. 1885. Catalogue of the lizards in the British Museum (Natural History). Volume II, Iguanidae, Xenosauridae, Zonuridae, Anguidae, Anniellidae, Helodermatidae, Varanidae, Xantusiidae, Teiidae, Amphisbaenidae, Second edition. Trustees of the British Museum, UK.

. 1890. First report on additions to the lizard collection in the British Museum (Natural History). Proceedings of the Zoological Society of London 1890:77-86.

Brongersma, L. D. 1946. On an Alopoglossus from Surinam. Zoologische Mededeelingen 14:231-236.

Castoe, T. A., T. M. Doan, and C. L. Parkinson. 2004. Data partitions and complex models in Bayesian analysis: the phylogeny of gymnophthalmid lizards. Systematic Biology 53:448-469. https://doi.org/10. $1080 / 10635150490445797$.

Cope, E. D. 1876. Report on the reptiles brought by Professor James Orton from the middle and upper Amazon, and western Peru.
Journal of the Academy of Natural Sciences of Philadelphia 8:159_ 183.

Dewynter, M., E. A. Courtois, J.--C. de Massary, Q. Uriot, S. Uriot, V. Premel, B. Villette, V. Rufray, M. Perrier, L. Bouchet, et al. 2020. La base de données Faune-Guyane (Amphibiens, Squamates, Tortues \& Caïmans): synthèse 2019. Herp me! 2:1-86

Duellman, W. E. 1973. Descriptions of new lizards from the upper Amazon Basin. Herpetologica 29:228-231.

FitZINGER, L. J. F. J. 1826. Neue Classification der Reptilien nach ihren Naturlichen Verwandtschaften nebst einer Verwandtschafts-Tafe und einem Verzeichnisse der Reptilien-Sammlung des K. K. Zoologisch Museum's zu Wien. J.G. Heubner, Austria. https://doi. org/10.5962/bhl.title.4683.

Fouguet, A., C. Cassini, C. F. B. Haddad, N. Pech, and M. T. Rodrigues, 2014. Species delimitation, patterns of diversification and historical biogeography of a Neotropical frog genus; Adenomera (Anura, Leptodactylidae). Journal of Biogeography 41:855-870. https://doi. org/10.1111/jbi.12250.

FRANÇA, F. G. R., AND N. M. VENÂNCIO. 2010. Reptiles and amphibians of a poorly known region in southwest Amazonia. Biotemas 23:71-84. https://doi.org/10.5007/2175-7925.2010v23n3p71.

Goicoechea, N., D. R. Frost, I. De la Riva, K. C. M. Pellegrino, J. Sites, M T. Rodrigues, AND J. M. PAdial. 2016. Molecular systematics of teioid lizards (Teioidea/Gymnophthalmoidea: Squamata) based on the analysis of 48 loci under tree-alignment and similarity-alignment. Cladistics 2016:1-48. https://doi.org/10.1111/cla.12150.

Hammer, Ø., D. A. T. Harper, And P. D. Ryan. 2001. Past: Paleontological statistics software package for education and data analysis. Palaeontologia Electronica 4:1-9.

HARrIS, D. M. 1994. Review of the teiid lizard genus Ptychoglossus. Herpetological Monographs 8:226-275. https://doi.org/10.2307/ 1467082.

Hoogmoed, M. S. 1973. Notes on the herpetofauna of Surinam IV. The lizards and amphisbaenians of Surinam. Biogeographica 4:1-419. https: / /doi.org/10.1007/978-94-010-2706-9_1.

KöHLER, G., H.-H. DietherT, AND M. Veselý. 2012. A contribution to the knowledge of the lizard genus Alopoglossus (Squamata: Gymnophtalmidae). Herpetological Monographs 26:173-188. https: / / doi.org/ 10.1655/HERPMONOGRAPHS-D-10-00011.1.

KoK, P. J. R., M. BitTenbinder, J. van DEN BerG, S. Marques-Souza, P. M. S. Nunes, A. Laking, M. Teixeira Jr., A. Fouguet, D. Means, R MACCUlloch, ET AL. 2018. Integrative taxonomy of the gymnophthalmid lizard Neusticurus rudis Boulenger, 1900, identifies a new species in the eastern Pantepui region, north-eastern South America. Journal of Natural History 52:1029-1066. https://doi.org/10.1080/ 00222933.2018 .1439541$.

LiNNAEUS, C. 1758. Systema naturae per regna tria naturae, secundum, classes, ordines, genera, species, cum characteribus, differentiis, synonymis, locis, Tomus I, Editio Decima, Reformata. Holmiae, Impensis Direct, Sweden. https://doi.org/10.5962/bhl.title.542.

Morales, C. M., M. J. Sturaro, P. M. S. Nunes, S. Lotzkat, and P. L. V. PELoso. 2020. A species-level total evidence phylogeny of the microteiid lizard family Alopoglossidae (Squamata: Gymnophthalmoidea). Cladistics 36:301-321. https://doi.org/10.1111/cla.12407.

Nunes, P.M.S., A. Fouquet, F. F. Curcio, P. J. R. KoK, AND M. T. Rodrigues. 2012. Cryptic species in Iphisa elegans Gray, 1851 (Squamata: Gymnophthalmidae) revealed by hemipenial morphology and molecular data. Zoological Journal of the Linnean Society 166:361376. https://doi.org/10.1111/j.1096-3642.2012.00846.x.

O'SHAughnessy, A. W. E. 1881. An account of the collection of lizards made by Mr. Buckley in Ecuador, and now in the British Museum, with descriptions of the new species. Proceedings of the Zoological Society of London 1881:227-245. https://doi.org/10.1111/j.10963642.1881.tb01282.x

Passos, P., L. O. Ramos, A. Fouquet, and A. L. C. Prudente. 2017. Taxonomy, morphology and distribution of Atractus flammigerus Boie, 1827 (Serpentes: Dipsadidae). Herpetologica 73:349-363. https: / / doi.org/10.1655/Herpetologica-D-16-00086.

Pellegrino, C. M., M. T. Rodrigues, Y. Yonenaga-Yassuda, and J. W. Sites. 2001. A molecular perspective on the evolution of microteiid lizards (Squamata, Gymnophthalmidae), and a new classification for the family. Biological Journal of the Linnean Society 74:315-338. https: / doi.org/10.1006/bij1.2001.0580.

Peloso, P. L. V., AND C. H. Morales. 2017. Description of a new species of Alopoglossus Boulenger, 1885 from Western Colombia (Gymnophthalmoidea). South American Journal of Herpetology 12:89-98. https: / / doi.org/10.2994/SAJH-D-16-00059.1. 
Peracca, M. G. 1904. Rettili ed amfibii. Bollettino dei Musei di Zoologia ed Anatomia comparata della R. Universitá di Torino 19:1-41. https://doi.org/10.5962/bhl.part.11596.

Ribeiro-Júnior, M. A. 2015a. Catalogue of distribution of lizards (Reptilia: Squamata) from the Brazilian Amazonia. I. Dactyloidae, Hoplocercidae, Iguanidae, Leiosauridae, Polychrotidae, Tropiduridae. Zootaxa 3983:1-110. https://doi.org/10.11646/zootaxa.3983.1. 1 .

- 2015b. Catalogue of distribution of lizards (Reptilia: Squamata) from the Brazilian Amazonia. II. Gekkonidae, Phyllodactylidae, Sphaerodactylidae. Zootaxa 3981:1-55. https://doi.org/10.11646/ zootaxa.3981.1.1

_ - 2018. A new species of Alopoglossus lizard (Squamata, Alopoglossidae) from the Southern Guiana Shield, northeastern Amazonia, with remarks on diagnostic characters to the genus. Zootaxa 4422:25-40. https://doi.org/10.11646/zootaxa.4422.1.2.

Ribeiro-JúnIOR, M. A., AND S. AMARAL. 2016a. Catalogue of distribution of lizards (Reptilia: Squamata) from the Brazilian Amazonia. III. Anguidae, Scincidae, Teiidae. Zootaxa 4205:401-430. https://doi. org/10.11646/zootaxa.4205.5.1.

- 2016b. Diversity, distribution, and conservation of lizards (Reptilia: Squamata) in the Brazilian Amazonia. Neotropical Biodiversity 2:195-421. https://doi.org/10.1080/23766808.2016. 1236769.

12017. Catalogue of distribution of lizards (Reptilia: Squamata) from the Brazilian Amazonia. IV. Alopoglossidae, Gymnophthalmidae. Zootaxa 4269:151-196. https://doi.org/10.11646/zootaxa.4269. 2.1 .

Ribeiro-Júnior, M. A., T. A. Gardner, and T. C. S. Ávila-Pires. 2008. Evaluating the effectiveness of herpetofaunal sampling techniques across a gradient of habitat change in a tropical forest landscape. Journal of Herpetology 42:733-749. https://doi.org/10.1670/07097R3.1.

Ribeiro-Júnior, M. A., M. B. Silva, And J. D. Lima. 2016. A new species of Bachia Gray 1845 (Squamata: Gymnophthalmidae) from the eastern Guiana Shield. Herpetologica 72:148-156. https://doi.org/10.1655/ HERPETOLOGICA-D-15-00030.

Ribeiro-Júnior, M. A., E. Choueri, S. Lobos, P. Venegas, O. TorresCarvajal, and F. Werneck. 2020. Eight in one: morphological and molecular analyses reveal cryptic diversity in Amazonian alopoglossid lizards (Squamata: Gymnophthalmoidea). Zoological Journal of the Linnean Society 190:227-270. https://doi.org/10.1093/ zoolinnean/zlz155.

Ruibal, R. 1952. Revisionary studies of some South American Teiidae. Bulletin of the Museum of Comparative Zoology 106:477-529.

Ruthven, A. G. 1924. Description of a new lizard of the genus Alopoglossus. Occasional Papers of the Museum of Zoology, University of Michigan 153:1-3.

SABAJ-PEREZ, M. H. 2016. Standard symbolic codes for institutional resource collections in herpetology and ichthyology: An online reference (v6.5). Available at http://www.asih.org/

Silva, M. B., M. A. Ribeiro-Júnior, and T. C. S. Ávila-Pires. 2018. A new species of Tupinambis Daudin, 1802 (Squamata: Teiidae) from Central South America. Journal of Herpetology 52:94-110. https://doi.org/ $10.1670 / 16-036$

Torres-Carvajal, O., AND S. E. Lobos. 2014. A new species of Alopoglossus lizard (Squamata, Gymnophthalmidae) from the tropical Andes, with a molecular phylogeny of the genus. ZooKeys 410:105-120. https://doi.org/10.3897/zookeys.410.7401.

Vacher, J.-P., J. Chave, F. Ficetola, G. Sommeria-Klein, S. TaO, C. Thébaud, M. Blanc, A. Camacho, J. Cassimiro, T. J. Colston, et al. 2020. Large scale DNA-based survey of Amazonian frogs suggest a vast underestimation of species richness and endemism. Journal of Biogeography, in press.

Accepted: 6 October 2020

Published online: XX Month XXXX

ZooBank: urn:lsid:zoobank.org:pub:572ED90F-52A4-4FD9-A76DE1EFA2244B17

\section{APPENDIX 1}

Referred Specimens.-Alopoglossus amazonius: BRAZIL: State of Rondônia: APL 14994, collected on 17 December 2009 by mammal team, at Morrinhos, Madeira River $\left(9^{\circ} 01^{\prime} 09.9^{\prime \prime} \mathrm{S}, 64^{\circ} 12^{\prime} 59.3^{\prime \prime} \mathrm{W}\right)$, Porto Velho; APL 15228, collected on 30 July 2010 by R. Fraga, at Bufalo, Madeira River ( $\left.9^{\circ} 08^{\prime} 34.2^{\prime \prime} \mathrm{S}, 64^{\circ} 30^{\prime} 57.4^{\prime \prime} \mathrm{W}\right)$, Porto Velho; APL 15428, collected on 8 August 2010 by A. Lima. at Jirau, right side of Madeira River $\left(9^{\circ} 19^{\prime} 30.2^{\prime \prime} \mathrm{S}, 64^{\circ} 42^{\prime} 32.9^{\prime \prime} \mathrm{W}\right)$, Porto Velho; APL 15947, collected on 11 November 2010 by Edi and Glaucio, at Pedra Island, Madeira River $\left(9^{\circ} 09^{\prime} 32^{\prime \prime} \mathrm{S}, 64^{\circ} 38^{\prime} 02^{\prime \prime} \mathrm{W}\right)$, Porto Velho; CHUNB 22680-91, collected on 27 December 2000 by G. Colli, at Guajará-Mirim ( $11^{\circ} 24^{\prime} 0.4^{\prime \prime}$ S, 64 $\left.54^{\circ} \mathrm{W}\right)$; MPEG 20511-12, collected on 5 February and 5 March 1998, at Guajará-Mirim State Park $\left(10^{\circ} 34^{\prime} 26.9^{\prime \prime} \mathrm{S}, 64^{\circ} 45^{\prime} 21.9^{\prime \prime} \mathrm{W}\right)$, Guajará-Mirim; MPEG 31439, collected on 7 October 2013 by A. Barros and K. Silva, at Santa Maria, Jamari National Forest $\left(9^{\circ} 09^{\prime} 03.9^{\prime \prime} S, 62^{\circ} 54^{\prime} 14.3^{\prime \prime} \mathrm{W}\right)$, Itapuã do Oeste; MZUSP 64339-40, collected on 4 August and 7 September 1985 by L. Vitt, at Santa Cruz da Serra $\left(10^{\circ} 40^{\prime}\right.$ S, $\left.62^{\circ} 34^{\prime} \mathrm{W}\right)$, Jaru MZUSP 67737-38, collected on 29 October 1986 and 8 November 1986 by ABC-CNRC, at Nazaré Waterfall, Machado River $\left(9^{\circ} 45^{\prime} \mathrm{S}\right.$, $\left.61^{\circ} 55^{\prime} \mathrm{W}\right)$, Vale do Anari; MZUSP 89342-44, collected on 7-14 July 2001 by UNIBAN, at Cacaulândia $\left(10^{\circ} 18^{\prime}\right.$ S, $\left.63^{\circ} 12^{\prime} \mathrm{W}\right)$; MZUSP 89965, collected on 20 May 1995, at Pacaás Novos Mountain $\left(10^{\circ} 45^{\prime} \mathrm{S}, 64^{\circ} 15^{\prime} \mathrm{W}\right)$, Nova Mamoré.

Alopoglossus andeanus: PERU: Madre de Dios Department: CORBIDI 13508, collected on 28 September 2013 by J. Malqui and G. Chávez, at El Parador, Inambari $\left(12^{\circ} 58^{\prime} 47^{\prime \prime} S, 70^{\circ} 14^{\prime} 6.25^{\prime \prime} S \mathrm{~W}\right)$, Tambopata; CORBIDI 17100, collected on 16 May 2013 by B. Crnobrna and H. Williams, at The Amazon Research and Conservation Center (ARCC), Las Piedras $\left(12^{\circ} 2^{\prime} 43.86^{\prime \prime} S\right.$, $69^{\circ} 40^{\prime} 42.07^{\prime \prime} \mathrm{S}$ W), Tambopata; CORBIDI 17713, collected on 28 June 2016 by G. Chávez and A. Barboza, at Conseción Río Las Piedras, Las Piedras (12 ${ }^{\prime} 8^{\prime} 38.04^{\prime \prime} S, 69^{\circ} 24^{\prime} 23^{\prime \prime} \mathrm{S}$ W), Tambopata; USNM 222340, collected on 5 November 1979 by R. McDiarmid, at ca. $30 \mathrm{~km}$ (airline) SSW of, Tambopata Reserve, Explorer's Inn $\left(12^{\circ} 50^{\prime} \mathrm{S}, 6^{\circ} 17^{\prime} \mathrm{W}\right)$, Puerto Maldonado; USNM 247489, collected on 16 September 1984 by R. Cocroft, at ca. $30 \mathrm{~km}$ (airline) SSW of. Tambopata Reserve, Explorer's Inn $\left(12^{\circ} 50^{\prime} \mathrm{S}, 6^{\circ} 17^{\prime} \mathrm{W}\right)$, Puerto Maldonado.

Alopoglossus angulatus: BRAZIL: State of Amapá: IEPA LT47, Cajari Extractive Reserve, A3 ( $\left.0^{\circ} 33^{\prime} 57.8^{\prime \prime} \mathrm{S}, 52^{\circ} 16^{\prime} 33.1^{\prime \prime} \mathrm{W}\right)$, Laranjal do Jari municipality; IEPA Ac45, Cajari Extractive Reserve, Açaizal $\left(0^{\circ} 33^{\prime} 27^{\prime \prime} \mathrm{S}, 52^{\circ} 14^{\prime} 17^{\prime \prime} \mathrm{W}\right)$, Laranjal do Jari municipality; IEPA Bj10, Bj61, Cajari Extractive Reserve, Bom Jardim $\left(0^{\circ} 32^{\prime} 40^{\prime \prime} \mathrm{S}\right.$ $\left.52^{\circ} 17^{\prime} 09^{\prime \prime} \mathrm{W}\right)$, Laranjal do Jari municipality; IEPA RS92, RS54b, RS115, RS176, Iratapuru Sustainable Development Reserve $\left(0^{\circ} 16^{\prime} 35^{\prime \prime} \mathrm{N}, 53^{\circ} 06^{\prime} 22.9^{\prime \prime} \mathrm{W}\right)$, Laranjal do Jari municipality; IEPA 110, 114, 176, 218, 221, 245, Santo Antônio Hydroelectric Power Station $\left(0^{\circ} 39^{\prime} 02.2^{\prime \prime} \mathrm{S}, 52^{\circ} 30^{\prime} 23.9^{\prime \prime} \mathrm{W}\right)$, Laranjal do Jari municipality; IEPA ST17, ST94, ST108, Santo Antônio Waterfall, Jari River $\left(0^{\circ} 39^{\prime} 02.2^{\prime \prime} \mathrm{S}, 52^{\circ} 30^{\prime} 23.9^{\prime \prime} \mathrm{W}\right)$, Laranjal do Jari municipality; IEPA RS430, RS457, Cupixi River $\left(0^{\circ} 34^{\prime} 45.8^{\prime \prime} \mathrm{N}, 52^{\circ} 19^{\prime} 08.3^{\prime \prime} \mathrm{W}\right)$, Pedra Branca do Amapari municipality; IEPA TQ26, Tumucumaque $\left(1^{\circ} 35^{\prime} 44.7^{\prime \prime} \mathrm{N}, 52^{\circ} 29^{\prime} 31.7^{\prime \prime} \mathrm{W}\right)$, Serra do Navio municipality; MPEG 15127, collected on 18 November 1988, at margin of the Araguari River, end of Serra do Navio-Araguari highway $\left(0^{\circ} 50^{\prime} 53.1^{\prime \prime} \mathrm{N}\right.$, $\left.51^{\circ} 11^{\prime} 46.2^{\prime \prime} \mathrm{W}\right)$, Ferreira Gomes municipality, field number TCAP 973; MPEG 29762, collected on 20 October 2006 by C. Silva, at Mazagão municipality ( $\left.0^{\circ} 10.3^{\prime} \mathrm{S}, 51^{\circ} 43.3^{\prime} \mathrm{W}\right)$; MPEG 797-99, 1921, collected by M. Moreira, at upper Maracá River $\left(0^{\circ} 32^{\prime} \mathrm{N}, 52^{\circ} 12^{\prime} \mathrm{W}\right)$, Mazagão municipality; MPEG 15033, 15095, 15150-55, 15182-85, collected on 6-20 November 1988, at Serra do Navio municipality $\left(0^{\circ} 53^{\prime} 36^{\prime \prime} \mathrm{N}, 51^{\circ} 59^{\prime} 54^{\prime \prime} \mathrm{W}\right)$; MPEG 19585, 19595, 19597-98, 19611, 19613, collected on 1-27 November 2000 by D. Silvano, B. Pimenta, and U. Galatti, at Amapari Project, 50 north line $\left(0^{\circ} 51^{\prime} 47^{\prime \prime} \mathrm{N}\right.$ $\left.51^{\circ} 52^{\prime} 43^{\prime \prime} \mathrm{W}\right)$, Serra do Navio municipality; MPEG 19608, collected 
on 24 November 2000 by D. Silvano, B. Pimenta, and U. Galatti, at Amapari Project, 400 south line $\left(0^{\circ} 51^{\prime} 34^{\prime \prime} \mathrm{N}, 51^{\circ} 52^{\prime} 34^{\prime \prime} \mathrm{W}\right)$, Serra do Navio municipality; MZUSP 88450-55, collected on 15-19 June 2001 by M. Rodrigues and D. Pavan, at mouth of Camaipi Stream, Maracá River $\left(0^{\circ} 04^{\prime} 22^{\prime \prime} \mathrm{S}, 51^{\circ} 51^{\prime} 52^{\prime \prime} \mathrm{W}\right)$, Mazagão municipality, field numbers MTR 6266, MTR 6267, MTR 6280, MTR 6287, MTR 6359, MTR 6352, respectively; MZUSP 78180, collected on 12 May 1992 by Exp. S. Kasahara, at Vila Nova $\left(0^{\circ} 26^{\prime} \mathrm{S}, 51^{\circ} 48^{\prime} \mathrm{W}\right)$, Mazagão municipality, field number 92.6009. BRAZIL: State of Amazonas: AMNH 101947, collected on January-February 1966 by D. Cooper, at Manjuru River $\left(4^{\circ} \mathrm{S}, 57^{\circ} \mathrm{W}\right)$, Itaituba municipality; INPA-H 1320 , 18744-45, collected on 17 November 1993, 30 August 2004, and March 2003, by M. Martins, M. Pinto, and M. Pinto, at Adolpho Ducke Reserve ( $\left.2^{\circ} 57^{\prime} 29.2^{\prime \prime} \mathrm{S}, 5^{\circ} 55^{\prime} 38.7^{\prime \prime} \mathrm{W}\right)$, Manaus municipality; INPA-H 789, collected on November 1993 by M. Martins, at Adolpho Ducke Reserve, Cuieiras River (250'04.2's, $\left.60^{\circ} 29^{\prime} 53.5^{\prime \prime} \mathrm{W}\right)$, Manaus municipality; INPA-H 19794, collected on 10 February 2007 by V. Carvalho, at Federal University of Amazonas ( $\left.3^{\circ} 05^{\prime} 59.4^{\prime \prime} \mathrm{S}, 59^{\circ} 58^{\prime} 31.7^{\prime \prime} \mathrm{W}\right)$, Manaus municipality; INPA-H 20948, collected on September 2008 by L. Brito Jr, at Ponta Negra ( $\left.3^{\circ} 03^{\prime} 06.7^{\prime \prime} \mathrm{S}, 60^{\circ} 05^{\prime} 57.6^{\prime \prime} \mathrm{W}\right)$, Manaus municipality; INPA-H 9022, collected on November 1988 by G. Rebelo, at Tiradentes, Coroado ( $\left.3^{\circ} 04^{\prime} 32.6^{\prime \prime} \mathrm{S}, 59^{\circ} 58^{\prime} 39.3^{\prime \prime} \mathrm{W}\right)$, Manaus municipality; INPAH 147, 149, 202, collected between 21 April and 31 July 1987 by M. Martins, at Caititu Stream, Uatumã River, Balbina Hydroelectric Power Station $\left(1^{\circ} 47^{\prime} 28.1^{\prime \prime} \mathrm{S}, 59^{\circ} 48^{\prime} 10.3^{\prime \prime} \mathrm{W}\right)$, Presidente Figueiredo municipality; INPA-H 20118, collected on 23 November 2007 by L. Bonora, R. Bernhard, and R. Melina, at Silves municipality $\left(2^{\circ} 44^{\prime} 45.7^{\prime \prime} \mathrm{S}, 58^{\circ} 11^{\prime} 48^{\prime \prime} \mathrm{W}\right)$; MPEG 14018, 14277, 14405, 14416-17, collected between 7 January and 12 September 1985 by D. PeccininiSeale, A. Lima, and T. Ávila-Pires, at Adolpho Ducke Reserve, 25 $\mathrm{km}$ north of Manaus $\left(2^{\circ} 56^{\prime} 17.5^{\prime \prime} \mathrm{S}, 59^{\circ} 58^{\prime} 12^{\prime \prime} \mathrm{W}\right)$, Manaus municipality; MZUSP 10909, 76289, 79762, collected on 17 April 1962 and 2 October 1992 (last two specimens), at Ducke Reserve ( $2^{\circ} 57^{\prime} 13^{\prime \prime} \mathrm{S}$, $\left.59^{\circ} 55^{\prime} \mathrm{W}\right)$, Manaus municipality; MZUSP 57637, collected on 16 December 1981, at Manaus municipality $\left(3^{\circ} 07^{\prime} \mathrm{S}, 60^{\circ} \mathrm{W}\right)$; MZUSP 67052, collected on 1986 by B. Zimmerman, at INPA-WWF Reserves, central point $\left(2^{\circ} 23^{\prime} 57^{\prime \prime} \mathrm{S}, 59^{\circ} 58^{\prime} 51^{\prime \prime} \mathrm{W}\right)$, Rio Preto da Eva municipality; MZUSP 66144-45, collected on January 1986 by M. Rodrigues, at INPA-WWF Reserves, Gavião (2²6 $03^{\prime \prime}$, $\left.59^{\circ} 48^{\prime} 56^{\prime \prime} \mathrm{W}\right)$, Rio Preto da Eva municipality. BRAZIL: State of Pará: AAGARDA 6416, collected on 13-22 October 2012 by S. Mângia, at Maísa Farm $\left(3^{\circ} 14^{\prime} 20^{\prime \prime} S, 49^{\circ} 20^{\prime} 23^{\prime \prime} \mathrm{W}\right)$, Moju municipality; IEPA UHE445, UHE454, UHEIV204, TCD $\left(0^{\circ} 63^{\prime} 12^{\prime \prime} \mathrm{S}\right.$, $\left.52^{\circ} 50^{\prime} 09.3^{\prime \prime} \mathrm{W}\right)$, Almeirim municipality; INPA-H 26238-42, Trairão National Forest $\left(4^{\circ} 59^{\prime} 35.3^{\prime \prime} \mathrm{S}, 55^{\circ} 45^{\prime} 53.7^{\prime \prime} \mathrm{W}\right)$, Trairão municipality; MPEG 29595-604, collected on 3-8 December 2009 by M. RibeiroJúnior and team, at Preto River, Marajó Island $\left(0^{\circ} 25^{\prime} 47.8^{\prime \prime} \mathrm{S}\right.$, $\left.50^{\circ} 28^{\prime} 52.4^{\prime \prime} \mathrm{W}\right)$, Afuá municipality, field numbers MAR 1478, MAR 1480, MAR 1496, MAR 1479, MAR 1500, MAR 1526, MAR 1529, MAR 1565, MAR 1532, MAR 1568, respectively; MPEG 22764, collected on 15 September 2004 by T. Gardner and M. RibeiroJúnior, at área $95\left(0^{\circ} 41^{\prime} 45^{\prime \prime} \mathrm{S}, 52^{\circ} 48^{\prime} 32^{\prime \prime} \mathrm{W}\right)$, Almeirim municipality, field number 2424; MPEG 27609, collected on 29 October 2008 by M. Hoogmoed and W. Rocha, at Maicuru Biological Reserve $\left(0^{\circ} 50^{\prime} \mathrm{N}\right.$, $53^{\circ} 56.2^{\prime} \mathrm{W}$ ), Almeirim municipality, filed number CN 1563; MPEG 27542-43, collected on 8-10 December 2008 by M. Hoogmoed and A. Dangiollela, at Paru State Forest $\left(0^{\circ} 56.4^{\prime} S, 53^{\circ} 13.7^{\prime} \mathrm{W}\right)$, Almeirim municipality, field numbers CN1601, CN1911; MPEG 24993, 2500002, 25441, collected between 7 November 2007 and 15 January 2008 by J. Bernardi and C. Lima, at Tapuama, Belo Monte Hydroelectric Power Station ( $\left.3^{\circ} 36^{\prime} 39^{\prime \prime} \mathrm{S}, 52^{\circ} 20^{\prime} 26^{\prime \prime} \mathrm{W}\right)$, Altamira municipality, field numbers BMW 31, BMW 17, BMW 28, BMW 46, BMW 139, respectively; MPEG 24909, 24916, collected on 7-10 Novermber by M. Hoogmoed, A. Lima, and R. Rocha, at Caracol, Belo Monte Hydroelectric Power Station $\left(3^{\circ} 27.6^{\prime} \mathrm{S}, 51^{\circ} 40^{\prime} \mathrm{W}\right)$, Anapu municipality, field numbers BML 211, BML 119; MPEG 19902, collected on 23 November 2001, at Barcarena municipality (1 $34^{\prime} 20.5^{\prime \prime} \mathrm{S}$, $48^{\circ} 43^{\prime} 18.9^{\prime \prime} \mathrm{W}$ ), field number HERP 4656; MPEG 24290, collected on 20 October 2006 by F. Nunes and team, at Curuperé Stream $\left(1^{\circ} 34^{\prime} \mathrm{S}, 48^{\circ} 45^{\prime} \mathrm{W}\right)$, Barcarena municipality, field number BAR 70; MPEG 19903, collected on 23 November 2001, at km 10, Vila do Conde-Abaetetuba highway $\left(1^{\circ} 37^{\prime} 38.5^{\prime \prime} \mathrm{S}, 48^{\circ} 41^{\prime} 18.1^{\prime \prime} \mathrm{W}\right)$, Barcarena municipality, field number HERP 4657; MPEG 18125, collected on 5 January 1998, at Goeldi Museum ( $\left.{ }^{\circ} 27^{\prime} 03.7^{\prime \prime} \mathrm{S}, 48^{\circ} 26^{\prime} 42.9^{\prime \prime} \mathrm{W}\right)$, Belém municipality; MPEG 15626, 19070, collected on 20 April 1989 and 14 February 2000, at Mocambo Reserve (1 ${ }^{\circ} 26^{\prime} 30.7^{\prime \prime} \mathrm{S}$, $\left.48^{\circ} 26^{\prime} 21.7^{\prime \prime} \mathrm{W}\right)$, Belém municipality; MPEG 16670, collected on 23 April 19993, at Nina Ribeiro Street $\left(1^{\circ} 27^{\prime} 07.21^{\prime \prime} \mathrm{S}, 48^{\circ} 27^{\prime} 51.1^{\prime \prime} \mathrm{W}\right)$, Belém municipality; MPEG 233, 1918, Utinga $\left(1^{\circ} 25^{\prime} 13.6^{\prime \prime} \mathrm{S}\right.$, $\left.48^{\circ} 25^{\prime} 36.4^{\prime \prime} \mathrm{W}\right)$, Belém municipality; MPEG 14733, collected on 27 November 1987 by D. Neto, at Caruaca River, Castanhal Ranch, Marajó Island $\left(1^{\circ} 30^{\prime} \mathrm{S}, 50^{\circ} 21^{\prime} \mathrm{W}\right)$, Breves municipality, field number 24; MPEG14985, collected on 3 October 1988 by M. Silva, at km 18, Capanema-Bragança highway $\left(1^{\circ} 11^{\prime} 43^{\prime \prime} \mathrm{S}, 47^{\circ} 0^{\prime} 51.6^{\prime \prime} \mathrm{W}\right)$, Capanema municipality; MPEG 30020, collected on 28 March 2009 by M. Sturaro and J. Gomes, at Aldeia Nova ( $\left.4^{\circ} 38^{\prime} 23.2^{\prime \prime} \mathrm{S}, 56^{\circ} 17^{\prime} 26.2^{\prime \prime} \mathrm{W}\right)$, Itaituba municipality, field number MJS 134; MPEG 29441, 29468, collected on 11 October 2009 and 11 August 2011 by M. Hoogmoed and J. Nascimento, and A. Dourado and team, at Amazonia National Park $\left(4^{\circ} 37.5^{\prime} \mathrm{S}, 56^{\circ} 23.3^{\prime} \mathrm{W}\right)$, Itaituba municipality, field numbers MSH 7902, PRMT 15; MPEG 25041, 27838, 28502, 28577, collected between 25 February 2008 and 6 January 2011, at ALCOA, Adutora road $\left(2^{\circ} 27^{\prime} 11^{\prime \prime} \mathrm{S}, 56^{\circ} 09^{\prime} 10^{\prime \prime} \mathrm{W}\right)$, Juruti municipality; MPEG 28576, collected on 5 January 2011 by M. Gordo, L. Frazão and F. Corrêa, at Guaraná Stream $\left(2^{\circ} 33^{\prime} 13^{\prime \prime} \mathrm{S}, 5^{\circ} 13^{\prime} 33^{\prime \prime} \mathrm{W}\right)$, Juruti municipality, field number JUR 1186; MPEG 21853, 28239, collected on 3 August 2004 and 27 July 2010, by G. Maschio and R. Silva, and Herp team, at Mutum ( $\left.2^{\circ} 36^{\prime} 34^{\prime \prime} \mathrm{S}, 56^{\circ} 11^{\prime} 46^{\prime \prime} \mathrm{W}\right)$, Juruti municipality, field numbers ACP 04, JUR 1112; MPEG 28238, collected on 20 July 2010 by Herp team, at Prudente/Galiléia Stream $\left(2^{\circ} 32^{\prime} 51^{\prime \prime} \mathrm{S}\right.$, $\left.56^{\circ} 13^{\prime} 32^{\prime \prime} \mathrm{W}\right)$, Juruti municipality, field number JUR 1034; MPEG 17998, collected on 1 July 1997, at Tapirapé-Aquiri National Forest $\left(5^{\circ} 46^{\prime} 26^{\prime \prime} \mathrm{S}, 50^{\circ} 30^{\prime} 46^{\prime \prime} \mathrm{W}\right)$, Marabá municipality, field number Salobo-87; MPEG 17997, collected on 1 December 1997 by U. Galatti, R. Rocha, and A. Barros, at camp in Tapirapé-Aquiri National Forest $\left(5^{\circ} 48^{\prime} 06^{\prime \prime} \mathrm{S}, 50^{\circ} 30^{\prime} 58^{\prime \prime} \mathrm{W}\right)$, Marabá municipality, field number Salobo-286; MPEG 18022, collected on 1 December 1997 by U. Galatti, R. Rocha, and A. Barros, at Itacaiunas River, Tapirapé-Aquiri National Forest $\left(5^{\circ} 52^{\prime} 20.4^{\prime \prime} \mathrm{S}, 50^{\circ} 28^{\prime} 50.3^{\prime \prime} \mathrm{W}\right)$, Marabá municipality; MPEG 21435, collected on 01 August 1997 by R. Yuki and team, at Pirelli Farm $\left(1^{\circ} 24^{\prime} 57.7^{\prime \prime} \mathrm{S}, 48^{\circ} 17^{\prime} 58.5^{\prime \prime} \mathrm{W}\right)$, Marituba municipality, field number Pirelli-142; MPEG 16478, 16610, 19942, 20277, 20334, 20885-86, 20896, 20946, collected on ECFPn, Caxiuanã National Forest $\left(1^{\circ} 44^{\prime} 15.5^{\prime \prime} \mathrm{S}, 51^{\circ} 27^{\prime} 11^{\prime \prime} \mathrm{W}\right)$, Melgaço municipality; MPEG 20933, collected on 2 April 1998 by J. Bernardi and R. Rocha, at Arauá River, ECFPn, Caxiuanã National Forest $\left(1^{\circ} 45^{\prime} 58.2^{\prime \prime} \mathrm{S}\right.$,

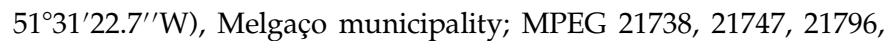
collected between 26 November 2003 and 12 April 2004 by G. Maschio and A. Lima, at Caiçara, ECFPn, Caxiuanã National Forest $\left(1^{\circ} 47^{\prime} 20.9^{\prime \prime} \mathrm{S}, 51^{\circ} 26^{\prime} 11.5^{\prime \prime} \mathrm{W}\right)$, Melgaço municipality; MPEG 28839, collected on 14 Novermer 2005 by G. Maschio and Calisto, at Marinaú, Caxiuanã National Forest $\left(1^{\circ} 49^{\prime} 51.4^{\prime \prime} \mathrm{S}, 51^{\circ} 20^{\prime} 26.5^{\prime \prime} \mathrm{W}\right)$, Portel municipality; MPEG 19311, 19337, 19350, 19376-77, 1940507, collected between 24 November and 16 December 2000 by R. Rocha, J. Bernardi, and G. Silva, at Arroz Cru, Belo Monte 
Hydroelectric Power Station $\left(3^{\circ} 23^{\prime} 27^{\prime \prime}\right.$ S, $\left.51^{\circ} 55^{\prime} 30^{\prime \prime} \mathrm{W}\right)$, Vitória do Xingu municipality; MPEG 24904-08, 24910-15, 24917-19, 2543340, 25657, collected between 5 November 2007 and 18 January 2008 by M. Hoogmoed, A. Lima, and R. Rocha, at Bom Jardim, Belo Monte Hydroelectric Power Station $\left(3^{\circ} 24.8^{\prime} \mathrm{S}, 51^{\circ} 45.8^{\prime} \mathrm{W}\right)$, Vitória do Xingu municipality; MZUSP 7681, collected between 20 October and 5 December 1959 by A. Hoge, at Marajó Island $\left(0^{\circ} 49^{\prime} \mathrm{S}\right.$, $49^{\circ} 08^{\prime} \mathrm{W}$ ), Cachoeira do Arari municipality; MZUSP 53697, collected on 8 February 1979 by M Rodrigues, at Buburé, Tapajós River, Amazonia National Park $\left(4^{\circ} 39^{\prime} 02^{\prime \prime} \mathrm{S}, 56^{\circ} 23^{\prime} 24^{\prime \prime} \mathrm{W}\right)$, Itaituba municipality; MZUSP 52488, 53630, collected on 31 October 1978 and 29 January 1979 by M. Rodrigues, at Uruá, Tapajós River, Amazonia National Forest $\left(4^{\circ} 30^{\prime} \mathrm{S}, 56^{\circ} 16^{\prime} \mathrm{W}\right)$, Itaituba municipality; MZUSP 53683-84, collected 1-5 February 1979 by M. Rodrigues, at Limão Waterfall, Tapajós River $\left(4^{\circ} 41^{\prime} \mathrm{S}, 56^{\circ} 21^{\prime} \mathrm{W}\right)$, Trairão municipality; MZUSP 67482-89, collected between 23 January and 3 March 1987 by L. Vitt, at Juruá, Xingu River $\left(3^{\circ} 24^{\prime} \mathrm{S}, 51^{\circ} 53^{\prime} \mathrm{W}\right)$, Vitória do Xingu municipality; USNM 158083, collected on 16 August 1965 by P. Humphrey, at Belém municipality $\left(1^{\circ} 26^{\prime} \mathrm{S}, 48^{\circ} 29^{\prime} \mathrm{W}\right)$, field number PHS 32125; USNM 162209, collected on 22 July 1966 by P. Humphrey, at IPEAN $\left(1^{\circ} 27^{\prime} \mathrm{S}, 48^{\circ} 29^{\prime} \mathrm{W}\right)$, Belém municipality; USNM 288896-97, collected on 1-2 February 1981 by R. Crombie and G. Busack, at Tapajós River, Amazonia National Park, ca. 66 km SW of Itaituba $\left(1^{\circ} 41^{\prime} 25.9^{\prime \prime} \mathrm{S}, 56^{\circ} 26^{\prime} 35.6^{\prime \prime} \mathrm{W}\right)$, Itaituba municipality, field number USNM-FS 046930, USNM-FS 046942. FRENCH GUIANA: MNHN-RA-2002.601, collected on 22 July 2002 by P. Gaucher and JC. De Massary, at Saint Marcel (2.39, -53.01); MNHN-RA-1950.22, collected by A. de la Rüe, at Bienvenue, Canopi (3.17, -52,34); MNHN-RA-2015.40, collected on 3 March 2015 by N. Vidal, at Crique Alama, borne 1, Mitaraka (2.27, -54.51); MNHN-RA2020.0024, Toponowoni; MNHN-RA-2020.0025, Awala; MNHNRA-2020.0026, Mont Galbao; MNHN-RA-2020.0027, MNHN-RA2020.0028, Mont Lucifer; MNHN-RA-2020.0029, Terrain Comté; MNHN-RA-2020.0030, DZ no 5; MNHN-RA-2020.0031, Gaa Kaba; MNHN-RA-2020.0032, Mana. GUYANA: Upper Demerara-Berbice: AMNH 151893, collected on 11 March 1997 by C. Cole and C. Townsend, at Berbice River Camp at ca. $18 \mathrm{mi}$ (linear) SW Kwakwani, ca. 2 mi downriver from Kurudini River confluence $\left(5^{\circ} 05^{\prime} 06^{\prime \prime} \mathrm{N}, 58^{\circ} 14^{\prime} 14^{\prime \prime} \mathrm{W}\right)$; USNM 566400, collected on 11-14 March 1997 by C. Cole and C. Townsend, at Kwakwani, ca. 18 mi (airline) SW of, ca. 2 mi downriver from confluence of Berbice River and Kurudini River, Berbice River camp $\left(5^{\circ} 05^{\prime} 06^{\prime \prime} \mathrm{N}, 58^{\circ} 14^{\prime} 14^{\prime \prime} \mathrm{W}\right)$. Upper Takutu-Upper Essequibo: AMNH 61381, collected on April 1938 by R. Snedigar, at Marudi $\left(2^{\circ} 18^{\prime} \mathrm{N}, 59^{\circ} 01^{\prime} \mathrm{W}\right)$. SURINAME: Brokopondo: AMNH 119395, collected on 8 July 1980 by C. Cole, C. Townsend and J. Cole, at Brownsberg Nature Park, trail to Irene Falls \& Toeval meertje $\left(4^{\circ} 56^{\prime} 49.9^{\prime \prime} \mathrm{N}, 55^{\circ} 09^{\prime} 28.5^{\prime \prime} \mathrm{W}\right)$. SURINAME: RMNH 15200, collected on 20 August 1961 by M. Hoogmoed, at Brown's Mountain [Brownsberg] ( $\left.4^{\circ} 56^{\prime} \mathrm{N}, 55^{\circ} 10^{\prime} \mathrm{W}\right)$; RMNH.RENA.4858, collected on 2 December 1910 by K. Hulk, at forest on the Lucie River.

Alopoglossus avilapiresae: BRAZIL: State of Acre: MPEG 20667-84 (667, 668, 671, 680, females; 683, male; others juveniles), Juruá River, $5 \mathrm{~km}$ north of Porto Walter ( $\left.8^{\circ} 15^{\prime} 31.2^{\prime \prime} \mathrm{S}, 72^{\circ} 46^{\prime} 37.1^{\prime \prime} \mathrm{W}\right)$, between 14 February and 17 Abril 1996, Vitt, Ávila-Pires, Caldwell \& Oliveira, field number LJV 6167, 6242, 6280, 6288, 6291, 6294, 6322, 6363, 6380, 6395, 6411, 6423, 6437, 6523, 6574, 6607, 6633, 6645, sequentially; MPEG 30374-76, males, Porto Walter, Sobral, on left side of Juruá River ( $\left.8^{\circ} 22^{\prime} \mathrm{S}, 72^{\circ} 49^{\prime} \mathrm{W}\right), 11-14$ March 1992, Gascon; MZUSP 53504, collected on 15 January 1979 by P. Vanzolini, at Porto Walter municipality $\left(8^{\circ} 16^{\prime} \mathrm{S}, 72^{\circ} 44^{\prime} \mathrm{W}\right)$, field number 783684 ; MZUSP 88649, collected on 20-22 November 2000 by M. Barbosa, at Estirão do Panela, Serra do Divisor National Park $\left(8^{\circ} 52^{\prime} \mathrm{S}\right.$, $72^{\circ} 47^{\prime} \mathrm{W}$ ), Marechal Thaumaturgo municipality, field number MBS 16. BRAZIL: State of Amazonas: AMNH 113136-40, collected on 18-28 May 1970 by B. Malkin, at Belém Stream, near Solimões River, ca. $40 \mathrm{~km}$ E of Leticia $\left(3^{\circ} 55^{\prime} \mathrm{S}, 69^{\circ} 37^{\prime} \mathrm{W}\right)$, Tabatinga municipality; CHUNB 13534-35, collected by R. Brandão, at Codajás municipality $\left(3^{\circ} 12^{\prime} \mathrm{S}, 62^{\circ} 42^{\prime} \mathrm{W}\right)$, field numbers UNB 2322, UNB 2320; CHUNB 13632 , collected at Amanã municipality $\left(3^{\circ} 30^{\prime} \mathrm{S}, 61^{\circ} 36^{\prime} \mathrm{W}\right)$, field number UNB 2323; INPA-H 9515, collected on 5 February 2001 by A. Duarte, at Maraã municipality, Amanã, Baré $\left(2^{\circ} 28^{\prime} 54.95^{\prime \prime} \mathrm{S}\right.$ $\left.64^{\circ} 42^{\prime} 36.98^{\prime \prime} \mathrm{W}\right)$, field number RCV 01-322; INPA-H 9514, collected on 30 Januery 2001 by A. Duarte, at Amanã, Baré $\left(2^{\circ} 28^{\prime} 54.9^{\prime \prime} S\right.$, $\left.64^{\circ} 42^{\prime} 37^{\prime \prime} \mathrm{W}\right)$, field number RCV 01-274; INPA-H 9394, collected on 1 February 2001 by A. Duarte, at Amanã, Boa Esperança $\left(2^{\circ} 29^{\prime} 17.6^{\prime \prime} S\right.$, $64^{\circ} 45^{\prime} 12.9^{\prime \prime} \mathrm{W}$ ), field number RCV 01-292; INPA-H 9382, collected on 12 January 2001 by A. Duarte, at Amanã, Boa Vista ( $2^{\circ} 20^{\prime} 32.7^{\prime \prime}$, $\left.64^{\circ} 51^{\prime} 33.8^{\prime \prime} \mathrm{W}\right)$, field number RCV 01-74; INPA-H 11112, 11119 collected on 9 September 2003 and 6 September 2006 by R. Bernhard, at Maraã, Mamirauá Sustainable Development Reserve, Paraná Trail ( $2^{\circ} 21^{\prime} 42.68^{\prime \prime}$ S, 65 $65^{\circ} 15^{\prime} 35.45^{\prime \prime}$ W) INPA-H 19847, collected on 2 September 2007 by V. Carvalho and M. Gordo, at km 19 AM352 road $\left(3^{\circ} 09^{\prime} 29.2^{\prime \prime} \mathrm{S}, 60^{\circ} 42^{\prime} 49.1^{\prime \prime} \mathrm{W}\right)$, Novo Airão municipality; MPEG 4652, female, São Gabriel da Cachoeira, Missão Salesiana do Jauareté, Turí River, affluent of the right side of the Uaupés River, Santa Cruz $\left(0^{\circ} 30^{\prime} 30.85^{\prime \prime} \mathrm{N}, 69^{\circ} 25^{\prime} 48.46^{\prime \prime} \mathrm{W}\right), 12$ March 1971, Moreira; MPEG 16003, female, Tabatinga $\left(4^{\circ} 13^{\prime} 57.59^{\prime \prime} \mathrm{S}, 69^{\circ} 56^{\prime} 23.16^{\prime \prime} \mathrm{W}\right), 22$ December 1989, Ávila-Pires, field number TCAP 1863; MZUSP 13060, collected on 8-28 April 1966 by B. Malkin, at Belém Stream, Solimões River $\left(3^{\circ} 55^{\prime} \mathrm{S}, 69^{\circ} 37^{\prime} \mathrm{W}\right)$, Tabatinga municipality; MZUSP 38369, collected on 12-18 January 1975 by Expedition MZUSPUSNM, at Beruri municipality $\left(3^{\circ} 54^{\prime} 09^{\prime \prime} \mathrm{S}, 61^{\circ} 20^{\prime} 22^{\prime \prime} \mathrm{W}\right)$, field number 741611. COLOMBIA: Amazonas Department: MCZ 141227, collected on 14 November 1973 by M. Corn, at near Amazon River, Leticia municipality $\left(4^{\circ} 12^{\prime} 22^{\prime \prime} \mathrm{S}, 69^{\circ} 56^{\prime} \mathrm{W}\right)$. PERU: Department of Cusco: CORBIDI 8321, collected on 28 November 2010 at La Convención Province, KP 50, Nativa Poyentimari Community $\left(12^{\circ} 11^{\prime} 18.73^{\prime \prime} \mathrm{S}, 73^{\circ} 0^{\prime} 3.32^{\prime \prime} \mathrm{W}\right)$. PERU: Department of Huánuco: CORBIDI 14749, collected on May 2014 by K. García, at Cacataibo, Codo del Pozuzo $\left(9^{\circ} 29^{\prime} 25.51^{\prime \prime} \mathrm{S}, 75^{\circ} 30^{\prime} 47.34^{\prime \prime} \mathrm{W}\right)$, Puerto Inca municipality. PERU: Department of Junín: CORBIDI 15836, collected on 25 July 2014 by E. Almora, at Portillo Alto, Fundo Santa Teresa, Río Negro $\left(11^{\circ} 10^{\prime} 9,72^{\prime \prime} \mathrm{S}, 74^{\circ} 38^{\prime} 54,9^{\prime \prime} \mathrm{W}\right)$, Satipo municipality. PERU: Department of Loreto: CORBIDI 15219, collected on 17 October 2014 by P. Venegas, at Campamento Anguila, Tapiche $\left(6^{\circ} 15^{\prime} 54^{\prime \prime} \mathrm{S}, 73^{\circ} 54^{\prime} 36^{\prime \prime} \mathrm{W}\right)$, Requena municipality; CORBIDI 1579, collected on November 2008 by M. Medina, at Campamento San Jacinto, Trompeteros $\left(2^{\circ} 42^{\prime} 15.6^{\prime \prime} \mathrm{S}, 76^{\circ} 18^{\prime} 46.2^{\prime \prime} \mathrm{W}\right)$, Loreto municipality; CORBIDI 1711, collected on 7 October 2008 by P. Venegas, at

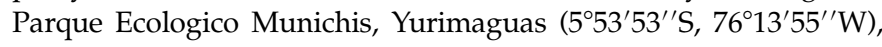
Alto Amazonas municipality; CORBIDI 2276, collected on 1 November 2008 by D. Vásquez, at Sierra del Divisor, Soplin $\left(6^{\circ} 55^{\prime} 7.4^{\prime \prime} \mathrm{S}, 76^{\circ} 50^{\prime} 46^{\prime \prime} \mathrm{W}\right)$, Requena municipality; CORBIDI 4111, 4126, collected on January 2009 by R. Santa Cruz, at Sierra del Divisor, Zona de Amortiguamiento, Alto Tapiche $\left(6^{\circ} 31^{\prime} 13^{\prime \prime} \mathrm{S}\right.$, $\left.74^{\circ} 1^{\prime} 0.1^{\prime \prime} \mathrm{W}\right)$, Requena municipality; CORBIDI 4770 , collected on March 2008 by V. Duran, at Andoas, Trompeteros $\left(2^{\circ} 40^{\prime} 15.6^{\prime \prime} \mathrm{S}\right.$, $\left.76^{\circ} 18^{\prime} 46.2^{\prime \prime} \mathrm{W}\right)$, Loreto municipality; CORBIDI 5964, collected on 16 October 2009 by P. Venegas, at Campamento Curupa, Napo $\left(2^{\circ} 53^{\prime} 7.6^{\prime \prime} \mathrm{S}, 73^{\circ} 1^{\prime} 4.7^{\prime \prime} \mathrm{W}\right)$, Maynas municipality; CORBIDI 6326, collected on 16 February 2010 by P. Venegas, at Centro de Investigacion Jenaro Herrera, Jenaro Herrera $\left(4^{\circ} 53^{\prime} 43.78^{\prime \prime} \mathrm{S}\right.$, $\left.73^{\circ} 39^{\prime} 2.97^{\prime \prime} \mathrm{W}\right)$, Requena municipality; CORBIDI 8763, collected on 19 November 2010 by C. Landauro, at Morona, Sector 2 ( $\left.3^{\circ} 11^{\prime} 13.14^{\prime \prime} \mathrm{S}, 77^{\circ} 26^{\prime} \mathrm{W}\right)$, Datem del Marañón municipality. PERU: 
Department of Madre de Dios: CORBIDI 18297, collected on 17 August 2016 by A. Garcia-Ayachi, at Las Piedras Amazon Center, Tambopata $\left(12^{\circ} 4^{\prime} 14.8^{\prime \prime} \mathrm{S}, 69^{\circ} 29^{\prime} 57.5^{\prime \prime} \mathrm{W}\right)$, Tambopata municipality. PERU: Department of Puno: CORBIDI 13176, collected by P. Venegas and L. Lujan, at Parque Nacional Bahuaja SoneneCampamento Satelite, Ayapata $\left(13^{\circ} 14^{\prime} 23.81^{\prime \prime} \mathrm{S}, 70^{\circ} 8^{\prime} 27.4^{\prime \prime} \mathrm{W}\right)$, Carabaya municipality. PERU: Department of San Martín: CORBIDI 16160, collected on 27 February 2014 by G. Chávez, at Concesión Palmito, Caynarachi $\left(6^{\circ} 10^{\prime} 45.14^{\prime \prime} \mathrm{S}, 76^{\circ} 18^{\prime} 37.32^{\prime \prime} \mathrm{W}\right)$, Lamas municipality; CORBIDI 3662, collected on April 2002 by P. Venegas, at Río Chambira, Shamboyacu $\left(7^{\circ} 2^{\prime} 15.03^{\prime \prime} S, 76^{\circ} 5^{\prime} 26.25^{\prime \prime} \mathrm{W}\right)$, Picota municipality.

Alopoglossus carinicaudatus: PERU: Department of Loreto: CORBIDI 297, collected on 9 October 2007 by P. Venegas and M. YanezMuñoz, at Redondococha, Teniente Manuel Clavero $\left(0^{\circ} 34^{\prime} 16.7^{\prime \prime} \mathrm{S}\right.$, $\left.75^{\circ} 13^{\prime} 9.19^{\prime \prime} \mathrm{W}\right)$, Putumayo; CORBIDI 12663, collected on 26 October 2012 by P. Venegas, at Medio Campuya, Rosa Panduro (1'31'3.4'S, $\left.73^{\circ} 48^{\prime} 58.2^{\prime \prime} \mathrm{W}\right)$, Putumayo. ECUADOR: Department of Orellana: QCAZR 6362, collected on 22 February 2003 by S. Ron, at Parque Nacional Yasuní, Estación Científica Yasuní PUCE, sendero Ceiba $\left(0^{\circ} 40^{\prime} 32.74^{\prime \prime} \mathrm{S}, 76^{\circ} 23^{\prime} 45.82^{\prime \prime} \mathrm{W}\right)$, Alejandro Labaka; QCAZR 11600, collected on 22 March 2013 by F. Ayala, at Parque Nacional Yasuní, Tambococha ( $\left.0^{\circ} 58^{\prime} 42.2^{\prime \prime} \mathrm{S}, 75^{\circ} 25^{\prime} 32.48^{\prime \prime} \mathrm{W}\right)$, Nuevo Rocafuerte; QCAZR 5216, collected on 11 June 2012 by M. Read, at Vía Pompeya Sur-Iro, cerca del Km 83, Sitio Auditivo A33 $\left(0^{\circ} 51^{\prime} 0.82^{\prime \prime} \mathrm{S}\right.$, $\left.76^{\circ} 17^{\prime} 25.97^{\prime \prime} \mathrm{W}\right)$; QCAZR 9144, collected on 6 September 2009 by S. Ron, at Vía Pompeya Sur-Iro, km 80, puente sobre el Río Beye ( $\left.0^{\circ} 50^{\prime} 24.43^{\prime \prime} \mathrm{S}, 76^{\circ} 18^{\prime} 8.68^{\prime \prime} \mathrm{W}\right)$, Cononaco.

Alopoglossus collii: BRAZIL: State of Mato Grosso: MZUSP 9793435 , collected by Op. Coatá, at UHE Guaporé $\left(15^{\circ} 07^{\prime} \mathrm{S} 58^{\circ} 58^{\prime} \mathrm{W}\right)$, Vale de São Domingos; UFMT 4105, PCH Ombreiras Margem direita do rio Jauru $\left(15^{\circ} 19^{\prime} 2.3^{\prime \prime} \mathrm{S}, 58^{\circ} 51^{\prime} 42.8^{\prime \prime} \mathrm{W}\right)$. State of Rondônia: CHUNB 18037-40, 18599, collected between 01 July and 24 August 2000 by

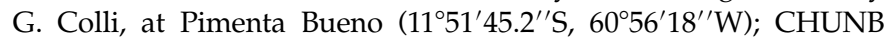

11472, collected between 20 August and 22 September 1999 by D. Mesquita, at Vilhena $\left(12^{\circ} 07^{\prime} 19.1^{\prime \prime} \mathrm{S}, 60^{\circ} 16^{\prime} 39.1^{\prime \prime} \mathrm{W}\right)$; MPEG 21951, collected on 20 July 2001, at Fazenda Jaburi $\left(11^{\circ} 38^{\prime} 02^{\prime \prime}\right.$, $\left.60^{\circ} 43^{\prime} 51^{\prime \prime} \mathrm{W}\right)$, Espigão do Oeste.

Alopoglossus meloi: BRAZIL: State of Amazonas: CZPB-RP 0027, collected on 22 September 2011 by A. Almeida, D. Oliveira, L. Frazão, S. Marques and T. Hrbek, at São José do Jatobá Village, Igarapé do Tabocal, eastern Jatapú River, São Sebastião do Uatumã municipality $\left(1^{\circ} 55^{\prime} 53^{\prime \prime} \mathrm{S}, 58^{\circ} 15^{\prime} 21^{\prime \prime} \mathrm{W}\right)$, field number CZPB-2940; MPEG 29381, collected on 05 October 2009 by R. Ávila, at Marajatuba, Urucará municipality $\left(2^{\circ} 22^{\prime} 47^{\prime \prime} \mathrm{S}, 57^{\circ} 38^{\prime} 42^{\prime \prime} \mathrm{W}\right)$, field number M3 R74. BRAZIL: State of Pará: MHNCI 13588, adult female, collected on June 2009 by F. Oliveira, at Saracá-Taquera National Forest, Oriximiná municipality $\left(1^{\circ} 44^{\prime} 11^{\prime \prime} \mathrm{S}, 56^{\circ} 24^{\prime} 36^{\prime \prime} \mathrm{W}\right)$; MHNCI 13950, Almeidas Plateau, Saracá-Taquera National Forest; MPEG 24372, collected on 29 January 2007 by E. Pereira and team, at Porto Trombetas, Aramã Plateau, Terra Santa municipality $\left(1^{\circ} 52^{\prime} 25^{\prime \prime} \mathrm{S}, 56^{\circ} 24^{\prime} 55^{\prime \prime} \mathrm{W}\right)$, field number R138; MPEG 15348 and MPEG 16201, collected on 06 December and 11 December 1988 by M. Hoogmoed, T. Ávila Pires and R. Rocha, at Cruz Alta, $6 \mathrm{~km}$ south of Trombetas River, Oriximiná municipality $\left(1^{\circ} 30^{\prime} 56^{\prime \prime} \mathrm{S}\right.$, $56^{\circ} 45^{\prime} 51^{\prime \prime} \mathrm{W}$ ), field number TCAP 1153 and TCAP 1213; MPEG 28271, collected on 29 June 2008 by R. Pinto and team, at Porto Trombetas, Saracá-Taquera National Forest, Saracá Plateau, Oriximiná municipality $\left(1^{\circ} 41^{\prime} 20^{\prime \prime} \mathrm{S}, 56^{\circ} 29^{\prime} 35^{\prime \prime} \mathrm{W}\right)$, field number R 212 ; MPEG 19880, collected on 10 October 2001 by U. Galatti and J. Bernardi, at Porto Trombetas, Saracá Mine, in a reforestation area, Oriximiná municipality $\left(1^{\circ} 40^{\prime} 41^{\prime \prime} \mathrm{S}, 56^{\circ} 23^{\prime} 57^{\prime \prime} \mathrm{W}\right)$, field number TROMBE 058; MPEG 24373, collected on 05 February 2007 by E. Pereira and team, at Porto Trombetas, Greig Plateau, Terra Santa municipality ( $\left.1^{\circ} 50^{\prime} 39^{\prime \prime} \mathrm{S}, 56^{\circ} 31^{\prime} 42^{\prime \prime} \mathrm{W}\right)$, field number R 201; MZUSP 53791-94, 54357-58, Taboleiro Leonardo, Trombetas River; MZUSP 78122, 78207-08, Vai-Quem-Quer. 

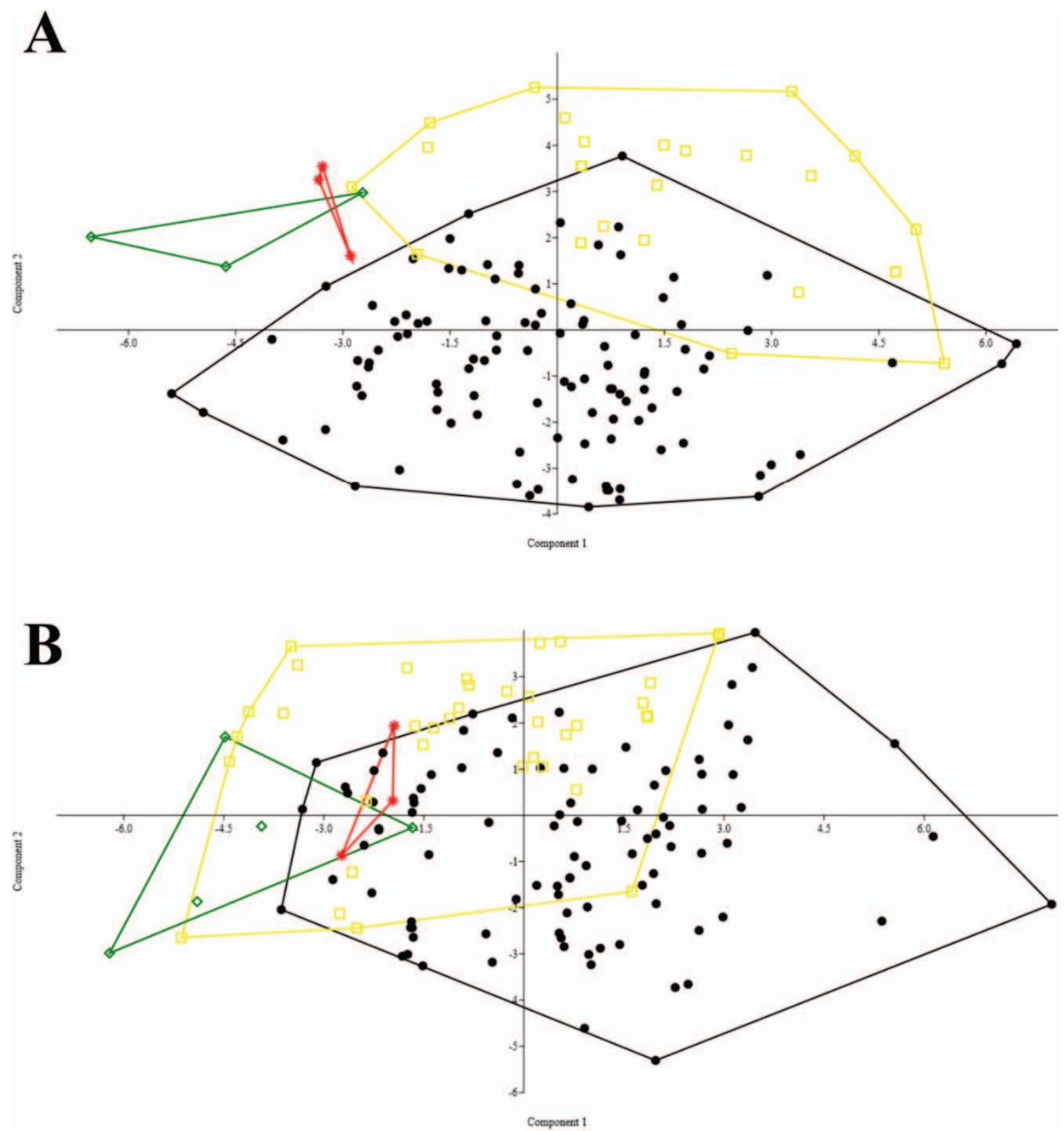

FIG. A1. Principal component analysis (PCA) of meristic characters considering only males (A) and only females (B) between specimens of $A$. angulatus (black dots), A. avilapiresae (yellow squares), A. meloi (green diamonds), and "Alopoglossus sp." (red stars). 
This article has been edited and typeset from the submitted materials. Please check proofs carefully for accuracy and follow the Allen Press Guide to PDF Annotation when marking revisions. Do not edit the PDF directly.

If present, queries will be listed below with corresponding numbers in the margins or may appear as PDF comments addressed to the author or editor. If a correction is desired in response to a query, mark the necessary changes directly in the proof using the appropriate annotation tool. If no change is desired, please highlight the query number in the margins and mark "No change needed" or reply to the PDF annotation with "No change needed".

1. Author: Per the use of "e.g.," in literature citations, please verify that all such instances are in fact examples and not direct citations, and delete "e.g." from any of the latter throughout the manuscript. Copy editor

2. Author: The abbreviation is missing for scale rows around the tail. Copy editor

3. Author: Are final publication data now available to replace "in press" in ref Vacher 2020? Copy editor

4. Author: Please explain meaning of em dash in cells in Table 2. Copy editor 